\title{
Sweet sorghum for phytoremediation and bioethanol production
}

Ming-Zhao Xiao', Qian Sun', Si Hong ${ }^{1}$, Wei-Jing Chen ${ }^{1}$, Bo Pang ${ }^{1}$, Zhi-Yan Du², Wen-Bin Yang ${ }^{3}$, Zhuohua Sun ${ }^{1}$ and Tong-Qi Yuan ${ }^{1 *}$

\begin{abstract}
As an energy crop, sweet sorghum (Sorghum bicolor (L.) Moench) receives increasing attention for phytoremediation and biofuels production due to its good stress tolerance and high biomass with low input requirements. Sweet sorghum possesses wide adaptability, which also has high tolerances to poor soil conditions and drought. Its rapid growth with the large storage of fermentable saccharides in the stalks offers considerable scope for bioethanol production. Additionally, sweet sorghum has heavy metal tolerance and the ability to remove cadmium (Cd) in particular. Therefore, sweet sorghum has great potential to build a sustainable phytoremediation system for $\mathrm{Cd}$-polluted soil remediation and simultaneous ethanol production. To implement this strategy, further efforts are in demand for sweet sorghum in terms of screening superior varieties, improving phytoremediation capacity, and efficient bioethanol production. In this review, current research advances of sweet sorghum including agronomic requirements, phytoremediation of $\mathrm{Cd}$ pollution, bioethanol production, and breeding are discussed. Furthermore, crucial problems for future utilization of sweet sorghum stalks after phytoremediation are combed.
\end{abstract}

Keywords: Sweet sorghum, Bioenergy crop, Phytoremediation, Cadmium, Bioethanol, Pretreatment Graphical Abstract
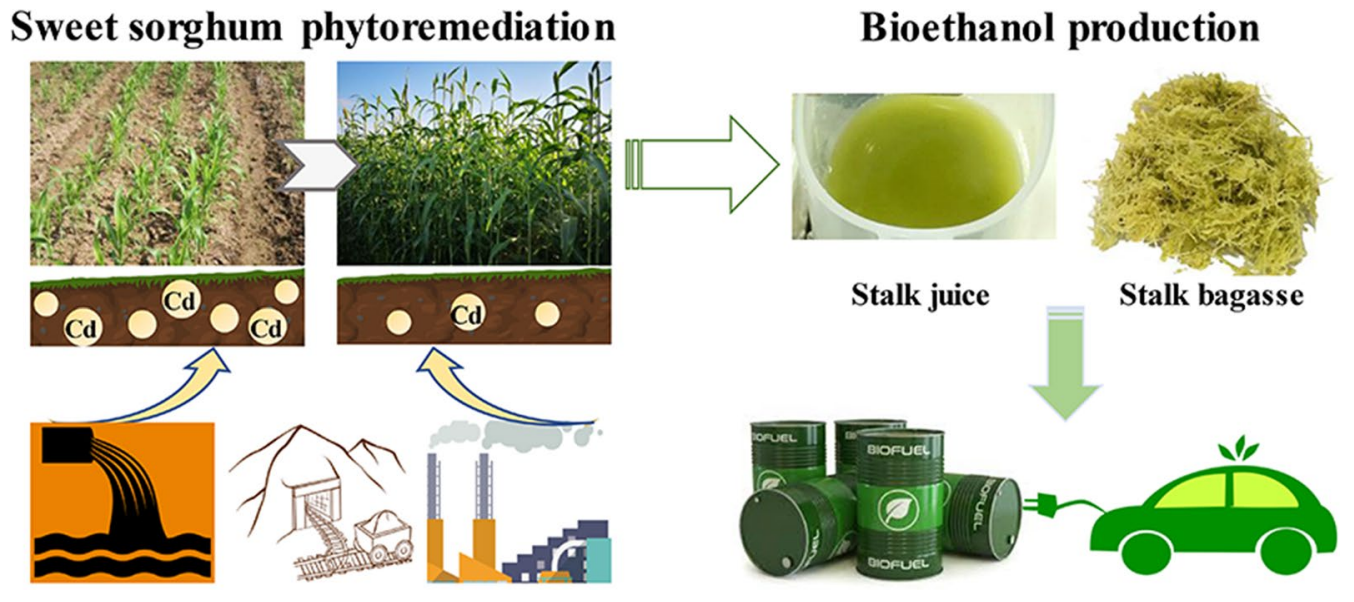

\footnotetext{
*Correspondence: ytq581234@bjfu.edu.cn

${ }^{1}$ Beijing Key Laboratory of Lignocellulosic Chemistry, Beijing Forestry University, Beijing 100083, China

Full list of author information is available at the end of the article
}

\section{Introduction}

As a consequence of contamination from increasing anthropogenic activities including mining, metal processing and smelting, industrial emissions, overuse of 
chemical products such as pesticides and fertilizers, and sewage irrigation, heavy metal (HM) pollution has become an increasingly serious problem worldwide [1, 2]. Various heavy metal(loids)s have contaminated more than $5 \times 10^{6}$ locus globally covering $2 \times 10^{9}$ hectares of land with soils [3]. Cadmium (Cd) is gaining attention as one of the most toxic HMs. According to the China Ecological Environment Status Bulletin in 2020, Cd is the primary HM contaminant in agricultural land [4]. Cd contamination modifies soil properties and induces soil degradation, resulting in the retardation of plant growth and substantial reductions in crop yield $[5,6]$. Worse still, $\mathrm{Cd}$ is non-biodegradable and can thus accumulate in the environment and subsequently contaminate the food chain via plant uptake, generating health risks such as teratogenic, mutagenic, and carcinogenic effects $[7,8]$. Therefore, there is an urgent need for remediation of $\mathrm{Cd}$ contaminated soil.

Various techniques for the remediation of HM contaminated soil have been reported. Most physical remediation techniques (e.g., soil replacement, thermal treatment, and electrokinetic remediation) and chemical remediation techniques (e.g., soil washing and flushing, chemical stabilization/immobilization, and solidification) have limitations, including high costs, operational complexity, low efficiency, and irreversible changes to soil properties $[9,10]$. Furthermore, chemical methods may generate groundwater pollution and increase the risk of secondary pollution [11]. In the mid-90 s, phytoremediation was proposed to rely on plants for the decontamination of polluted environment (phytovolatilization and phytoextraction) or stabilizing pollutant into harmless status (phytostabilization/phytoimmobilization) [10, 12]. Since this plant-based technology not only easy to operate but also economically viable, it is suitable for large and diffusely areas $[7,13]$. Although hyperaccumulators have high HM bioaccumulation rates, their slow growth and low biomass are not ideal. On the contrary, high biomass plants offer good potential for the phytoremediation of soils, which can compensate for their low metal concentrations with high-yielding ability $[14,15]$.

For HM contaminated arable land, growing suitable metal-tolerant energy crops to remove HM while harvesting valuable energy products can be a viable economic alternative of land management strategy to food or feed production $[12,16,17]$. Furthermore, cultivation of energy crops on contaminated land would address the food-versus-fuel issue favorably. With this in mind, researchers have examined the HM tolerance of sweet sorghum and evaluated its HM absorption capacity [12, 18, 19]. Especially, recent studies have confirmed that some sweet sorghum varieties could achieve effective $\mathrm{Cd}$ removal while producing large biomass in $\mathrm{Cd}$-enriched farmland [20-22]. Therefore, sweet sorghum is considered as a promising candidate for bridging phytoremediation and bioethanol production and thus prevent HM from entering the food chain.

Throughout the world, over $80 \%$ of energy sources still come from fossil fuels. However, the increasing depletion of fossil fuel and concerns associated environment has shifted worldwide attention to cleaner energy. Renewable fuel production from biomass has been considered a way to reduce the overdependence on fossil fuels [23-25]. Currently, as a biodegradable and renewable resource, bioethanol is the most consumable biofuel in the transportation sector, and has a brilliant future in easing the global energy crisis as well as the environmental pressure [26]. As shown in Fig. 1, global production of bioethanol has reached $2.9 \times 10^{10}$ gallons annually [27]. However, the first generation (1G) bioethanol production from starch- and sugar-based stocks endanger food security; the second generation (2G) bioethanol production from lignocellulose materials is still questionable in terms of technological challenge and economic feasibility $[25,28$, 29].

As an ideal energy crop for biofuel production, sweet sorghum is fast-growing and high biomass-producing $\mathrm{C}_{4}$ annual grass (refers to the plants using the $\mathrm{C} 4$ photosynthetic pathway which converts $\mathrm{CO}_{2}$ into 4-carbon intermediate), with outstanding adaptability to harsh conditions like drought, heat, waterlogging, and salinity [26]. It is widely cultivated in subtropical, tropical, and semi-arid tropical regions. The total aboveground fresh biomass yields range from 55 to $150 \mathrm{t} / \mathrm{ha}$ [30]. Compared with grain sorghum, sweet sorghum varieties are much taller and produce significantly higher biomass yields, with the fleshier and juicier stems but smaller seed heads

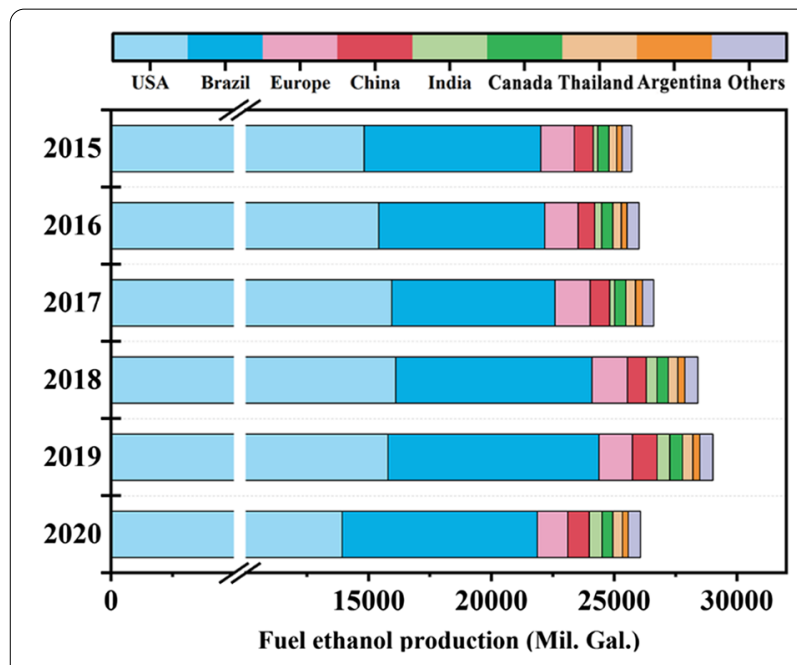

Fig. 1 Annual world fuel ethanol production from 2015 to 2020 [27] 
[31]. Some sweet sorghum lines can yield $78 \%$ of the total plant biomass in juice, with juice Brix of $15-23 \%$. The soluble fermentable sugars in the juice are comprised of $6-21 \%$ fructose, $9-33 \%$ glucose, and $53-85 \%$ sucrose [32, 33]. According to the previous report, dried sweet sorghum stalks (SSS) contained 50.7\% soluble sugars, 19.6\% cellulose, $15.2 \%$ hemicelluloses, and $3.2 \%$ acid insoluble lignin [34]. Due to the high production of both fermentable saccharides and lignocellulose, sweet sorghum is particularly suitable for producing various biofuels (e.g., biodiesel, bioethanol, biohydrogen, and biogas) and bio-based products (e.g., acetone, biobutanol, lactic acid, bacterial cellulose, and reinforcement additives for geopolymers) [35-40]. Especially due to the high soluble sugar contents, the bioethanol obtained from sweet sorghum could be taken as a 1.5 generation biofuel [41]. In contrast to other major sugar crops such as sugarcane and sugar beet, the demand for energy to produce raw sorghum juice for ethanol production is lower [42].

Phytoremediation of Cd-contaminated land by sweet sorghum would provide relatively positive remediation results and generate large amounts of biomass for bioethanol production with low input. Comparing with traditional physical and chemical remediation methods, this strategy is more environmentally friendly. And the utilization of sweet sorghum for bioenergy is more economically efficient than hyperaccumulators. Enabling this integrated strategy will be strongly conducive to improve the environmental and economic benefits of ecological restoration. Developing the comprehensive concept of phytoremediation combined with biorefinery will further establish guidance for remediation of other HM contaminated areas such as chromium $(\mathrm{Cr})$. Due to the extensive use of $\mathrm{Cr}$-containing tanning agents in the leather-based industries and the lack of appropriate disposal strategies of tanning sludge, the threats of $\mathrm{Cr}$ pollution from tannery to the surrounding environment should not be underestimated [43, 44]. Similarly, the selection of suitable energy crops for $\mathrm{Cr}$ phytoremediation may lead to a more sustainable and applicable approach.

This study provides an overview of researches on sweet sorghum relating to agronomic requirements, phytoremediation of Cd pollution, bioethanol production, and breeding. The characteristics of sweet sorghum in $\mathrm{Cd}$ phytoremediation are specifically discussed. The production of bioethanol from SSS is systematically elucidated. Then, targeted and comprehensive breeding aim is proposed. Finally, it critically assessed the potential and challenge for utilization of stalks after phytoremediation. Based on the significance of soil remediation, this paper is expected to contribute to the realization of sweet sorghum phytoremediation and simultaneous bioethanol production.

\section{Characteristics and growth conditions}

\subsection{Characteristics}

Sweet sorghum (Sorghum bicolor (L.) Moench) belongs to the grass family Poaceae, tribe Andropogoneae, and subtribe Sorghinae, originated in Africa. The genus Sorghum consists of those generally recognized as sorghum and some of their closer relatives, which is a group of plants with phenotypic, genetic, and geographic diversities. The enormous variation in the genus is divided into 22 species classified as five sections $[42,45,46]$. The term sweet sorghum is applied to distinguish those special genotypes with high accumulation of soluble sugars in the stem or sap [47]. At maturity, sweet sorghum can grow to a height of $250-580 \mathrm{~cm}$, with an elliptical or round head as well as wide flat leaves. The stems are resembling those of maize, nearly oval with groove. The root system of sweet sorghum is fibrous with profuse branching. Under a feasible environment, the strong adventitious roots can be produced by above-ground nodes that help anchor the plant to reduce lodging $[30,33]$. The $\mathrm{C}_{4}$ photosynthesis contributes to higher nitrogen and water use efficiency as well as overall robustness of sweet sorghum, enabling it to better survival in the dry regions with higher light intensity/temperatures [31].

The traits of sweet sorghum are particularly favorable as a biofuel feedstock, such as short duration (approximately 120 days), good tolerance of abiotic and biotic stress, high photosynthetic efficiency, fewer input requirements, as well as low cost of cultivation [31, 47, 48]. SSS is the most essential part for bioethanol production, accounting for about $70 \%$ of the total aboveground dry weight. Yields of soluble and structural carbohydrates in SSS depend on their varieties, growing environment, and harvest time [26, 49]. Additionally, Appiah-Nkansah et al. [32] summarized the characteristics of sweet sorghum suitable for bioethanol production: (1) high biomass yield; (2) thick and lodging-resistant stalks with juicy internodes; (3) high total soluble sugar content of juice; (4) high juice extraction rate; (5) a long period of industrial use; and (6) a range of sweet sorghum varieties with different maturity levels to extend the harvest season.

\subsection{Agronomic requirements}

Although native to the tropics, sweet sorghum adapts well to temperate regions. It can be cultivated between $45^{\circ} \mathrm{N}$ and $45^{\circ} \mathrm{S}$ latitude, at elevations between mean sea level and $1500 \mathrm{~m}$. Sweet sorghum is more heat tolerant than many other grain crops, with an optimum growth temperature of $32-34{ }^{\circ} \mathrm{C}$. The minimum temperature for germination is $7-10{ }^{\circ} \mathrm{C}$, and for growth is $15^{\circ} \mathrm{C}[30,47]$. Under suitable climatic conditions (low latitudes with more frost-free periods), sweet sorghum can ratoon after 
the main crop harvest, allowing for two cropping seasons in eight months [50].

Generally, sorghum can be cultivated successfully in multifarious soil conditions, including organic soils, calcareous soils, medium loams, and heavy clays, and can tolerant a soil $\mathrm{pH}$ range of 5.5-8.5 [30]. The most productive soil for sweet sorghum cultivation is well-structured and well-drained black or red clay loam soils with $\mathrm{pH}$ ranging between 6.5 and 7.5 [32, 47]. It was found that the nodal roots of sweet sorghum were longer and stronger in loam soil than those in clay soil, which had more efficient nutrient and water uptake, leading to a higher yield of juice, sugar content, and bagasse [51]. Sweet sorghum has strong resistance to saline-alkaline soils, which could produce sufficient sap, total carbohydrates, and bioethanol in fields with soil salinity up to $3.2 \mathrm{dS} / \mathrm{m}$ even if with a $25-50 \%$ reduction in irrigation [52]. Although sweet sorghum is generally tolerant of low nutrient levels and poor soil conditions, the balanced fertilization is required for a productive crop and the content of fertilizers varies with the level of N, P, and $\mathrm{K}$ in the soil profile [32, 53, 54]. The previous research found that sweet sorghum needs only $36 \%$ of the fertilizer $\mathrm{N}$ demanded by corn to obtain similar ethanol yields [55]. Considering the biomass, sugar yields, and nutrient recoveries, Erickson et al. pointed that the optimal requirements for the long-term whole plant harvesting were 90 to $110 \mathrm{~kg} \mathrm{~N} / \mathrm{ha}$ and 15 to $20 \mathrm{~kg}$ $\mathrm{P} /$ ha, respectively [56]. Besides, the $\mathrm{K}$ requirements are not low for high biomass yields of sweet sorghum, even though it only exhibits one critical $\mathrm{K}$ uptake stage, from elongation to anthesis. It has been reported that $\mathrm{K}$ uptake amounts ranged 109-300 kg/ha for the total aboveground dry weight of 13.2-35.2 t/ha [49, 57].

As known to be one of the most drought-tolerant crops, sorghum can remain dormant during drought and resume growth when appropriate conditions reappear. The large fibrous root system of sweet sorghum works effectively, which can extend up to a depth of $2 \mathrm{~m}$, with approximately twice the capacity to absorb water from the soil than corn [30, 31]. Under drought stress, it was found that the water use efficiency in sweet sorghum increased by $20 \%$ while decreased by $5 \%$ in maize. Zegada-Lizarazu et al. [58] proposed that the better drought resistance in sweet sorghum attributes to its capacity to improve the water use efficiency, enhance root length density, and maintain high leaf water potential as well as physiological activity under drought stress. Sorghum will survive with less than $300 \mathrm{~mm}$ (rain and irrigation in total) of water over the 100-day growth period. Nonetheless, sufficient moisture is crucial for plant maximum production. Sweet sorghum requires $500-1000 \mathrm{~mm}$ of water to obtain well yields of 50 to $100 \mathrm{t} /$ ha [47]. Besides, sweet sorghum is susceptible to sustained water logging. Thus, appropriate nutrient and water management are vital to optimizing biomass and sugar yields of sweet sorghum.

\section{Phytoremediation of $\mathrm{Cd}$ pollution}

\subsection{Physiological and biochemical responses, and the $\mathrm{Cd}$ accumulation mechanisms under $\mathrm{Cd}$ stress}

Previous studies have elucidated the physiological and biochemical responses of sweet sorghum under $\mathrm{Cd}$ stress in various aspects. Root is directly exposed to $\mathrm{Cd}$ thus the $\mathrm{Cd}$ stress could firstly reduce root activities, impede the absorption of water and nutrient, influence the cell cycle progression, and induce cell death in root tips of S. bicolor seedlings $[59,60]$. As shown in Fig. 2a, the distribution of $\mathrm{Cd}$-staining dye indicated that $\mathrm{Cd}$ primarily located in the meristematic zone. While the S-phase cells in the root tips labeled by EdU (ethynyl deoxyuridine) were reduced with increasing $\mathrm{Cd}$ concentration. Especially, the root activities showed negatively correlated with the $\mathrm{Cd}$ concentration at each growth stage [61]. During the seed germination and root growth of sweet sorghum, the $\mathrm{Cd}$ toxicity would impair the activities of hydrolyzing enzymes and the translocation of the hydrolyzed sugars from cotyledons to the growing embryonic axes, ultimately resulting in the reduction of germination and disruption of seedling growth [60]. For sweet sorghum seedlings, the chlorophyll (Chl) and carotenoid contents did not change significantly at low $\mathrm{Cd}$ exposure, but the decrease became increasingly severe with the increase of $\mathrm{Cd}$ stress. While the change of the shape of $\mathrm{Chl} a$ fluorescence transient, increase in $\mathrm{Chl} a / b$ ratio, reduction in stomatal conductance and transpiration rate, and obstructed electron transport in sorghum leaves have also been observed after $\mathrm{Cd}$ treatments. These demonstrated factors may together result in the decrease of photosynthetic activity of sorghum seedlings [61-64]. The ultrastructural alterations of sweet sorghum have been directly discovered under high $\mathrm{Cd}$ stress, including the impairment of the chloroplast structure (Fig. 2b) and the thickening of the cell walls of vascular bundle cells in leaves as well as xylem and phloem cells in roots [64].

The Cd-induced reactive oxygen species (ROS) could lead to oxidative damage in plants, including $\mathrm{O}^{2-}, \mathrm{OH}^{-}$, and $\mathrm{H}_{2} \mathrm{O}_{2}$. The oxidative stress to sweet sorghum under low Cd concentrations $(\leq 10 \mathrm{mg} / \mathrm{kg})$ stress could stimulate antioxidant defence system to eliminate ROS. While high levels of $\mathrm{Cd}(\geq 50 \mathrm{mg} / \mathrm{kg})$ would reduce the activities of antioxidant enzymes in sweet sorghum plant such as peroxidases and glutathione transferase, and overcome their quenching capacity, simultaneously causing cell damage $[62,66]$. The $\mathrm{Cd}$ stress could also alter the expression levels of auxin-related genes in the roots of sweet sorghum seedlings, thereby disturbing the homeostasis of auxin and ROS, resulting in the growth inhibition [59]. 


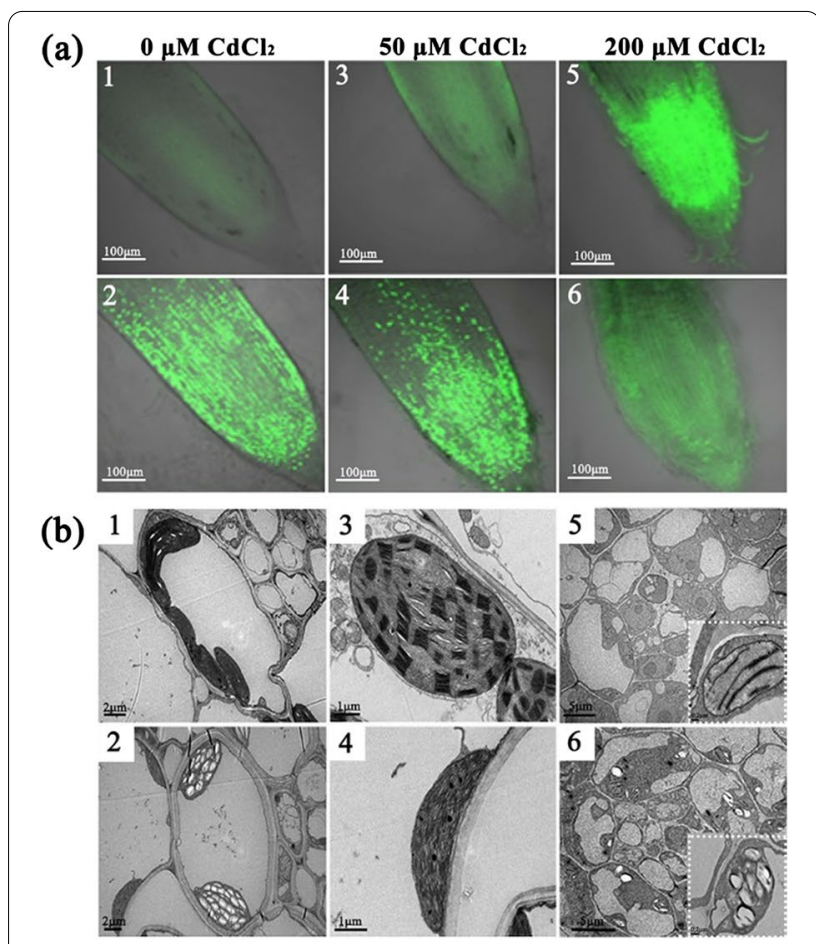

(c)

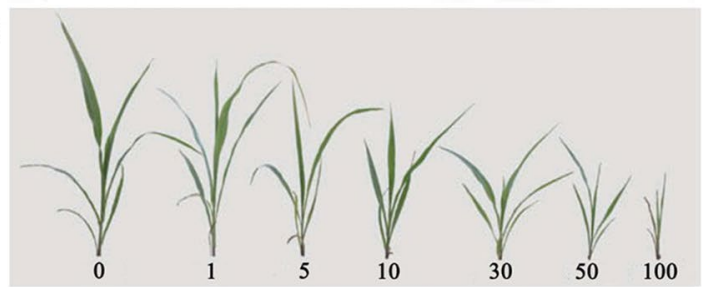

Fig. 2 Cd stress inhibits sweet sorghum plant growth. a Accumulation of $\mathrm{Cd}$ and $\mathrm{Cd}$ inhibited S-phase cell cycle progression in root tips. 1, 3, 5: Cd localization revealed by Leadmium Green AM staining in the root tips of $\mathrm{S}$. bicolor seedlings exposed to 0,50 , and $200 \mu \mathrm{M} \mathrm{CdCl}_{2}$ for 5 days. 2, 4, 6: Images generated by merging the confocal images of EdU-labeled cells with bright-field microscopy images. Adapted by permission from [59]. Springer Nature, Copyright (2017). b Transmission electron microscopic micrographs of chloroplast. Seedlings of sweet sorghum were treated with $0(1,3,5)$ and $100 \mu \mathrm{M}(2,4,6) \mathrm{Cd}$ for 30 days. 1 \& 2: Vascular bundle sheath cells in the Kranz anatomy of leaves. $3 \& 4$ : The chloroplast of mesophyll cells. 5 \& 6: The Kranz anatomy of caulicles. One separate chloroplast was illustrated in the bottom-right corner (scale bars $=0.2 \mu \mathrm{m}$ ). Reprinted by permission from [64]. Springer Nature, Copyright (2016). c Morphological responses to the increase of $\mathrm{Cd}$ concentration (0-100 mg/kg, the 51st day). Reprinted from [65], Taylor \& Francis Ltd, (http://www.tandfonline.com), Copyright (2015)

Additionally, $\mathrm{Cd}^{2+}$ may compete with bivalent metal ions (such as $\mathrm{Fe}^{2+}, \mathrm{Zn}^{2+}$, and $\mathrm{Mn}^{2+}$ ) for the transport binding sites and further interfere with the accumulation of micronutrients in sweet sorghum [67]. The inhibitory effect of $\mathrm{Cd}$ on sweet sorghum growth (Fig. 2c) determines that sweet sorghum is more adapted to soils with mild level of $\mathrm{Cd}$ contamination.
The molecular mechanisms of $\mathrm{Cd}$ uptake, translocation, and accumulation to sweet sorghum remain mostly unknown up to now. Feng et al. [67] have made great efforts to gain a preliminary understanding of these molecular mechanisms. Two sweet sorghum genotypes with contrasting $\mathrm{Cd}$ translocation factors were comparatively investigated (Accession No. PI 152873, with high-Cd accumulation; Accession No. PI 273969, with low-Cd accumulation). Not only did they differ greatly in the symplasmic Cd uptake by root, but the root anatomy structures also revealed differences in their endodermal apoplasmic barriers. Underlying these traits, many differentially expressed genes (DEGs) involved in cell wall metabolism and modification between these two genotypes were identified by transcriptome data, while DEGs encoding HM transporters were also examined. Besides, KEGG (Kyoto Encyclopedia of Genes and Genomes) pathway analysis showed over-representation of phenylpropanoid biosynthesis pathway both for $\mathrm{Cd}$ responsive DEGs and DEGs, indicating the importance of this pathway in $\mathrm{Cd}$ response and the differential $\mathrm{Cd}$ accumulation of sweet sorghum. Recently, Jia et al. [68] further performed a comparative analysis of small RNAs, degradome, and transcriptome in these two differential sweet sorghum genotypes to reveal the regulatory mechanisms behind $\mathrm{Cd}$ accumulation. Potential MicroRNAs with their target genes involved in sweet sorghum response to $\mathrm{Cd}$ stress were identified. These MicroRNA targets may participate in cell wall construction, transmembrane transportation, cytoskeleton activity, and ROS homeostasis.

Combined with the analyses of morpho-physiological traits and molecular mechanisms, Feng et al. [67] finally constructed a diagram to illustrate the key processes affecting the Cd uptake and translocation in sweet sorghum plants as displayed in Fig. 3a. It was proposed that the high $\mathrm{Cd}$ accumulation may be mainly realized by the synergy of multiple processes including efficient root uptake (Fig. 3a step 1), less root cell wall binding (Fig. 3a step 2), weak endodermis apoplasmic barriers (Fig. 3a step 3), and efficient xylem loading (Fig. 3a step 4). Furthermore, another previous study by their research team [64] showed that the distribution of $\mathrm{Cd}$ entering sweet sorghum seedlings was not homogeneous in different tissues. The localization of $\mathrm{Cd}$ was investigated in situ by dithizone staining method. The images of tissue sections (Fig. 3b) showed that $\mathrm{Cd}$ was mostly centralized in the stele of roots while dispersed in the intercellular space of caulicles.

\subsection{Cd Phytoremediation capacity}

The experiments relating to $\mathrm{Cd}$ phytoremediation by sweet sorghum are collated within Table 1. In 2005, 


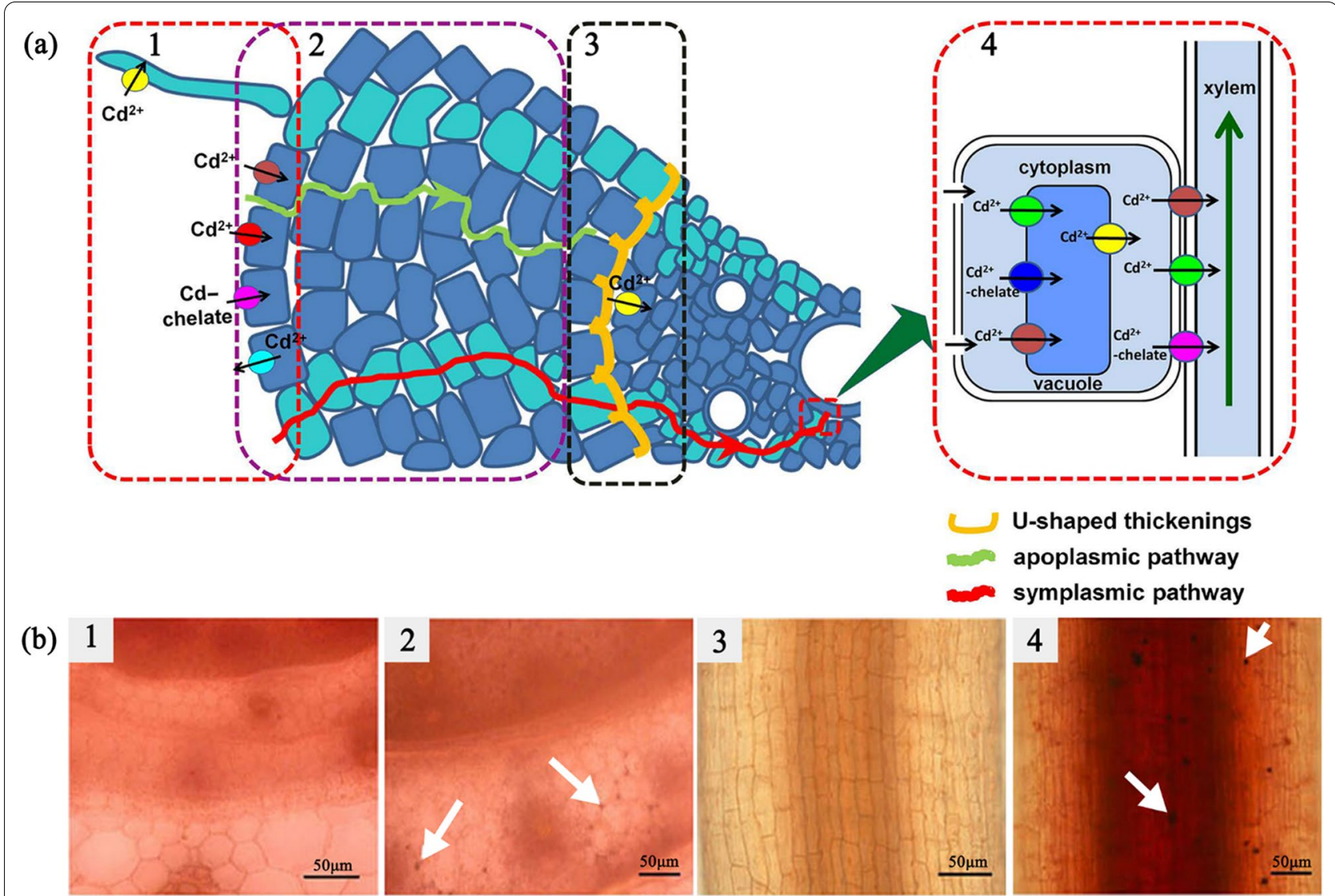

Fig. 3 The mechanisms of $\mathrm{Cd}$ accumulation in sweet sorghum plants and the localization of $\mathrm{Cd}$ in different tissues. a The main physiological processes involved in $\mathrm{Cd}$ uptake and translocation: 1, uptake of $\mathrm{Cd}$ from the external solution to root cells; 2 , cell wall binding of $\mathrm{Cd} ; 3$, apoplastic barriers in the endodermis; 4, Cd translocation via xylem. Adapted from [67], John Wiley \& Sons, Inc. Copyright (2017). b Cd-dithizone precipitates in caulicle $(1,2)$ and root $(3,4)$. Sweet sorghum seedlings were exposed to $0(1,3)$ or $100 \mu \mathrm{M}(2,4) \mathrm{Cd}$ concentration for 3 weeks. Adapted by permission from [64]. Springer Nature, Copyright (2016)

Marchiol et al. [18] conducted the first in situ field trial to estimate the phytoremediation ability of sweet sorghum in an industrial site polluted by pyrite cinders (located at Torviscosa, Italy). The absence of nutrients in the native soil significantly impeded the growth of sweet sorghum and therefore their removal of $\mathrm{Cd}$ was negligible. After treatment with mineral fertilization and organic amendment, sorghum could produce adequate biomass and absorb total Cd content of 5.62 and $4.31 \mathrm{~g} / \mathrm{ha}$, respectively. Meanwhile, the highest removal efficiency of HMs in the soil by sweet sorghum was $0.030 \%$ of As, $0.056 \%$ of $\mathrm{Cd}, 0.024 \%$ of $\mathrm{Co}, 0.225 \%$ of $\mathrm{Cu}, 0.018 \%$ of $\mathrm{Pb}$, and $0.082 \%$ of $\mathrm{Zn}$, respectively. Afterwards, Zhuang et al. [19] established a field plot experiment using sweet sorghum for polymetallic paddy soil phytoremediation. In the field site seriously polluted by lead and zinc mining wastewaters (Lechang, China), sweet sorghum Keller could achieve the total removal of $52 \mathrm{~g} /$ ha for $\mathrm{Cd}$ after 120-day cultivation without any treatments. Besides, the removals of $\mathrm{Zn}$ and $\mathrm{Cu}(1.44$ and $0.24 \mathrm{~kg} / \mathrm{ha}$, respectively) were also considerable. Another in situ phytoremediation experiment carried in industrially polluted regions near Plovdiv, Bulgaria also confirmed the synchronous accumulation of $\mathrm{Pb}, \mathrm{Cu}, \mathrm{Zn}$ and $\mathrm{Cd}$ in sweet sorghum [69]. Particularly, compared with other crops such as sunflower, maize, barley, and Nicotiana tabacum, sweet sorghum has the strongest $\mathrm{Cd}$ extraction in multiple HMs contaminated soil [19].

To explore the phytoremediation potential of sweet sorghums in soil with only Cd pollution, researchers further carried out targeted pot experiments. Yajin No.1 has been reported to have the highest Cd uptake of $2.47 \mathrm{mg} /$ plant when the Cd concentration in the soil was $30 \mathrm{mg} /$ $\mathrm{kg}$, meanwhile the aerial biomass was $82.1 \mathrm{~g} /$ plant [65]. Wang et al. [70] grew sweet sorghum in the pots with acidic sandy loam soil ( $\mathrm{pH}$ 6.1), and found that Nengsi 2 \# could absorb up to $2.70 \mathrm{mg} \mathrm{Cd} /$ plant under Cd stress of $15 \mathrm{mg} / \mathrm{kg}$ with the aboveground biomass of $36.1 \mathrm{~g} /$ plant. Similarly, a controlled plot experiment was performed to test the phytoremediation potential of sweet 
Table 1 Experiments relating to the sweet sorghum phytoremediation

\begin{tabular}{|c|c|c|c|c|c|c|c|c|}
\hline \multirow[t]{2}{*}{ Species } & \multirow{2}{*}{$\begin{array}{l}\text { Remediation } \\
\text { scale }\end{array}$} & \multicolumn{2}{|c|}{ Growing conditions } & \multirow{2}{*}{$\begin{array}{l}\text { Cultivation } \\
\text { time }\end{array}$} & \multirow{2}{*}{$\begin{array}{l}\text { Aerial } \\
\text { biomass dw }\end{array}$} & \multirow{2}{*}{$\begin{array}{l}\text { Cd } \\
\text { concentrations } \\
(p p m, d w)\end{array}$} & \multirow[t]{2}{*}{ Cd uptake } & \multirow[t]{2}{*}{ References } \\
\hline & & Type & $\begin{array}{l}\text { Total Cd } \\
\text { (ppm) }\end{array}$ & & & & & \\
\hline - & Field trial & $\begin{array}{l}\text { Native soil, } 142 \\
\mathrm{~m}^{2}\end{array}$ & 4.29 & 112 day & $1.54-22.1 \mathrm{t} / \mathrm{ha}$ & $\begin{array}{l}\text { Root } 1.35-1.75 \\
\text { Shoot } 0.20-0.26\end{array}$ & $0.31-5.62 \mathrm{~g} / \mathrm{ha}$ & [18] \\
\hline Keller, Mray, Rio & Field trial & $\begin{array}{l}\text { Paddy soil, } 288 \\
\mathrm{~m}^{2}\end{array}$ & 4.9 & 120 day & 18.7-25.8 t/ha & & $26-52 \mathrm{~g} / \mathrm{ha}$ & [19] \\
\hline Sugar sorghum & Field trial & $\begin{array}{l}\text { Calcaric Allu- } \\
\text { vial soil, } 25 \mathrm{~m}^{2}\end{array}$ & $2.5-26.2$ & $\begin{array}{l}\text { Reaching ripe- } \\
\text { ness }\end{array}$ & - & $\begin{array}{l}\text { Root } 1.1-7.5 \\
\text { Stem } 0.14-0.33\end{array}$ & - & {$[69]$} \\
\hline - & Pot test & $\begin{array}{l}\text { Vermiculite } \\
\text { with Hoagland } \\
\text { solution }\end{array}$ & 50 & 10 week & $0.94 \mathrm{~g} /$ plant & $\begin{array}{l}\text { Root } 88.8 \\
\text { Aerial part } 13.7\end{array}$ & - & [74] \\
\hline Six hybrids & Hydroponics & $\begin{array}{l}\text { Modified } \\
\text { Hoagland } \\
\text { solution }\end{array}$ & $200 \mu \mathrm{M}$ & 28 day & - & $\begin{array}{l}\text { Root } 0.44-1.1 \\
\text { Stem } 0.08-0.20\end{array}$ & - & {$[62]$} \\
\hline Yajin No.1 & Pot test & - & $\begin{array}{l}1,5,10,30,50 \\
100\end{array}$ & 167 day & $\begin{array}{l}12.5-111.7 \mathrm{~g} / \\
\text { plant }\end{array}$ & $\begin{array}{l}\text { Root 6.7-137.9 } \\
\text { Shoot 6.3-30.6 }\end{array}$ & $\begin{array}{l}0.48-2.47 \mathrm{mg} / \\
\text { plant } \\
52-271 \mathrm{~g} / \mathrm{ha}\end{array}$ & {$[65]$} \\
\hline- & Field trial & - & 4.52 & 120 day & 37.6/55.1 t/ha & $\begin{array}{l}\text { Root 3.4/3.9 } \\
\text { Shoot 0.3/0.5 }\end{array}$ & 11/23 g/ha & [75] \\
\hline $\mathrm{M}-81 \mathrm{E}$ & Hydroponics & $\begin{array}{l}\text { Modified } \\
\text { Hoagland } \\
\text { solution }\end{array}$ & $10,50,100 \mu \mathrm{M}$ & 30 day & - & $\begin{array}{l}\text { Root 435-3565 } \\
\text { Caulicle 27-68 }\end{array}$ & - & {$[64]$} \\
\hline & Pot test & $\begin{array}{l}\text { Humus- } \\
\text { vermiculite } \\
\text { mixture }\end{array}$ & 30 & 5 mon & - & $\begin{array}{l}\text { Root } 10 \\
\text { Stem 0.17-1.2 }\end{array}$ & - & \\
\hline $\begin{array}{l}\text { Cowley, Nengsi } \\
2 \#\end{array}$ & Pot test & $\begin{array}{l}\text { Acidic sandy } \\
\text { loam soil }\end{array}$ & 3,15 & 100 day & $\begin{array}{l}30.2-63.9 \mathrm{~g} / \\
\text { plant }\end{array}$ & $\begin{array}{l}\text { Root 9.7-46.1 } \\
\text { Stem 6.2-70.6 }\end{array}$ & $\begin{array}{l}0.49-2.70 \mathrm{mg} / \\
\text { plant } \\
50-280 \mathrm{~g} / \mathrm{ha}\end{array}$ & {$[70]$} \\
\hline M64 & $\begin{array}{l}\text { Field control } \\
\text { experiment }\end{array}$ & $\begin{array}{l}\text { Sieved natural } \\
\text { soil }\end{array}$ & $2.3-33.6$ & 167 day & $\begin{array}{l}126-194 \mathrm{~g} / \\
\text { plant }\end{array}$ & $\begin{array}{l}\text { Root 5.4-24 } \\
\text { Stalk 2.07-7.0 }\end{array}$ & $\begin{array}{l}0.43-1.23 \mathrm{mg} / \\
\text { plant }\end{array}$ & {$[71]$} \\
\hline $\begin{array}{l}96 \text { genotypes } \\
\text { of sorghum }\end{array}$ & Hydroponics & $\begin{array}{l}\text { Modified } \\
\text { Hoagland } \\
\text { solution }\end{array}$ & $10 \mu \mathrm{M}$ & 2 week & - & $\begin{array}{l}\text { Root } 277.0-898.3 \\
\text { Shoot } 19.0-202.4\end{array}$ & $\begin{array}{l}6.1-25.8 \mu \mathrm{g} / \\
\text { plant }\end{array}$ & {$[76]$} \\
\hline $\begin{array}{l}107 \text { sorghum } \\
\text { accessions }\end{array}$ & Field trial & $\begin{array}{l}\text { Alluvial soil, } \\
100 \mathrm{~m}^{2}\end{array}$ & 2.24 & 2 mon & - & $\begin{array}{l}\text { Leaf sheaths } \\
5.8-58.6 \\
\text { Nodes and inter- } \\
\text { nodes } 4.4-37.2\end{array}$ & - & [77] \\
\hline BL0602 & Pot test & Quartz sand & $50,100 \mu \mathrm{M}$ & 15 day & - & $\begin{array}{l}\text { Root } 91,135 \\
\text { Stem 27.5, } 31.3\end{array}$ & $\begin{array}{l}7.4,10.1 \mathrm{mg} / \\
\text { plant }\end{array}$ & {$[63]$} \\
\hline L69, H18 & Hydroponics & - & $10 \mu \mathrm{M}$ & 2 week & - & $\begin{array}{l}\text { Root 376, } 904 \\
\text { Shoot 32, } 208\end{array}$ & - & {$[67]$} \\
\hline Five hybrids & Field trial & $\begin{array}{l}\text { Cropland soil, } \\
21 \mathrm{~m}^{2}\end{array}$ & 2.0 & 5 mon & $\begin{array}{l}721-857 \mathrm{~g} / \\
\text { plant }\end{array}$ & $\begin{array}{l}\text { Root 1.9-4.5 } \\
\text { Stem 0.14-1.9 }\end{array}$ & $\begin{array}{l}2.5-6.0 \mathrm{mg} / \\
\text { plant }\end{array}$ & [20] \\
\hline $\begin{array}{l}166 \text { sorghum } \\
\text { accessions }\end{array}$ & Field trial & Farmland soil & $3.03,2.80$ & $\begin{array}{l}\text { Reaching } \\
\text { maturity }\end{array}$ & $\begin{array}{l}\text { 95.6-1236 g/ } \\
\text { plant }\end{array}$ & Stem 0.5-16.5 & $\begin{array}{l}0.12-1.6 \mathrm{mg} / \\
\text { plant }\end{array}$ & [21] \\
\hline Alto No.2 & Pot test & $\begin{array}{l}\text { Sieved paddy } \\
\text { soil }\end{array}$ & 1.22 & 90 day & $128 \mathrm{~g} / \mathrm{pot}$ & $\begin{array}{l}\text { Root } 5.25 \\
\text { Shoot } 3.75\end{array}$ & $0.48 \mathrm{mg} / \mathrm{pot}$ & [73] \\
\hline $\begin{array}{l}\text { Six sorghum } \\
\text { cultivars }\end{array}$ & Field trial & $\begin{array}{l}\text { Farmland soil, } \\
2 \text { ha }\end{array}$ & $0.25,0.96$ & 5 mon & 20.4-27.9 t/ha & Stalk 1.3-9.2 & $19.6-148 \mathrm{~g} / \mathrm{ha}$ & [22] \\
\hline Dalishi & Hydroponics & $\begin{array}{l}\text { Nutrient solu- } \\
\text { tion }\end{array}$ & $5 \mu \mathrm{M}$ & 10 day & $\begin{array}{l}0.12-0.25 \mathrm{~g} / \\
\text { plant }\end{array}$ & $\begin{array}{l}\text { Root } 140-300 \\
\text { Stem + sheath } \\
24.8-33\end{array}$ & $\begin{array}{l}17.4-43.6 \mu \mathrm{g} / \\
\text { plant }\end{array}$ & [72] \\
\hline
\end{tabular}


sorghum M64. It can be concluded that the Cd accumulation by M64 could reach up to $0.84 \mathrm{mg} /$ plant with the dry weight of $171 \mathrm{~g} /$ plant when the soil Cd concentration was $18 \mathrm{mg} / \mathrm{kg}$ [71]. Soils with gradient Cd concentrations were used in these pot experiments. Although the sorghum biomass decreased with the increase of Cd stress, higher $\mathrm{Cd}$ level was more conducive to the $\mathrm{Cd}$ transfer from soil into the plants. Therefore, the total Cd removal quantity of potted sorghum was closely related to the soil $\mathrm{Cd}$ concentration, and the best remediation result was achieved under the intermediate conditions $(15-30 \mathrm{mg} /$ $\mathrm{kg}$ ) of set $\mathrm{Cd}$ pollution.

Information gained in controlled pot conditions was limited, thus three field trials were conducted to verify the application perspective of sweet sorghum against the background of severe problem of Cd-polluted farmland in Hunan province, China. According to Yuan et al. [20], five species of hybrid sweet sorghum were planted in a cropland presenting a low contaminated soil with the $\mathrm{Cd}$ concentration of $2.0 \mathrm{mg} / \mathrm{kg}$ located at Chenzhou, Hunan. They found none of these hybrids showed obvious toxicity symptoms, while the hybrid 1794 had the highest $\mathrm{Cd}$ removal of $358 \mathrm{~g} / \mathrm{ha}$ and dry mass of $760 \mathrm{~g} /$ plant. A screening test of 166 sorghum accessions (including 124 sweet sorghum) was carried out in a typical Cd-polluted agricultural field in Zhuzhou, Hunan by Liu et al. [21]. After the growing season of 2016 and 2017 (soil Cd concentration of 3.03 and $2.80 \mathrm{mg} / \mathrm{kg}$ ), five optimal accessions were selected with the $\mathrm{Cd}$ accumulation ranging from 489 to $1174 \mu \mathrm{g} /$ plant and biomass above $698 \mathrm{~g} /$ plant. Field trials on real planting scales of 2 ha and 1.22 ha in Hunan were performed in 2017 and 2018 by Xiao et al. [22]. In the farmland with low $\mathrm{Cd}$ pollution (Cd concentration of 0.96 and $0.25 \mathrm{mg} / \mathrm{kg}$ ), six sorghum cultivars removed $\mathrm{Cd} 19.6-148 \mathrm{~g} / \mathrm{ha}$ after one crop and produced dry aerial biomass in the range of 20.4-27.9 t/ ha. Obviously, the $\mathrm{Cd}$ concentrations in farmland soils were much lower than those in pot test, and most sweet sorghum varieties could grow normally. But it was undeniable that the source of $\mathrm{Cd}$ pollution in the field was more complex and dynamic. Identifying sweet sorghums with high $\mathrm{Cd}$ absorption at low Cd pollution level and adapted to the local climate is significant for the promotion of practical application of phytoremediation.

\subsection{Promoting Cd removal}

The Cd removal capacity of sweet sorghum could be facilitated by appropriate agronomic practices, including soil fertility management, mobilizing agents, endophytic bacteria, and harvesting methods. Nitrogen fertilization is a common agricultural measure. High $\mathrm{NH}_{4}{ }^{+}$containing fertilizer can decrease soil $\mathrm{pH}$, leading to the increment in $\mathrm{Cd}$ uptake by plant. It is observed that the $\mathrm{NH}_{4} \mathrm{NO}_{3}$ and $\left(\mathrm{NH}_{4}\right)_{2} \mathrm{SO}_{4}$ treatments increased the biomass of sweet sorghum and minimally enhanced phytoextraction [19]. Through the hydroponics supplying nitrogen in the form of $\mathrm{Ca}\left(\mathrm{NO}_{3}\right)_{2}$, Bai et al. [72] further discovered that the $\mathrm{Cd}$ concentrations in sweet sorghum aboveground tissues displayed an inverted ' $U$ ' shape with increasing $\mathrm{N}$ levels under $\mathrm{Cd}$ stress. An optimum nitrate supply would increase both dry weight and $\mathrm{Cd}$ concentration, thereby resulting in higher efficiency of $\mathrm{Cd}$ phytoextraction. Organic mobilizing agents may mobilize HMs in soils and fertilize soils, moreover they are readily degradable. Applying the composited organic agents (citric acid + dissolved organic fertilizer) at heading stage achieved the maximum sorghum biomass and $\mathrm{Cd}$ bioaccumulation quantity, which were $3.8 \%$ and $48.8 \%$ higher than those of the control, respectively [73]. The plant-growth-promoting endophytes (PGPEs) with multiple HMs resistances originating from hyperaccumulator could facilitate the HM phytoremediation and biomass production of sweet sorghum. Sweet sorghums inoculation with the endophytic bacterial strain SLS18 significantly produced more biomass (increased by $38 \%$ ) than the control groups in Cd-polluted pots, resulting in the increased $\mathrm{Cd}$ removal with little change of $\mathrm{Cd}$ concentration in plant [74]. In addition, the double harvesting method would also enhance the phytoextraction efficiency of sweet sorghum by increasing total biomass yield. It has been reported that the biomass and total $\mathrm{Cd}$ uptake of sweet sorghum under double harvesting increase by about $46.5 \%$ and $109 \%$ respectively compared to single harvesting [75]. The $\mathrm{Cd}$ accumulation in stalks was discovered increasing with maturity. Consequently, harvesting sweet sorghum after the dough stage would be beneficial to enhance the removal of Cd [22]. Although EDTA is considered as one of the most effective chelating agents, it did not show evident effects on Cd bioaccumulation for sweet sorghum when used as soil amendment [19].

\subsection{Characteristics of sweet sorghum in Cd phytoremediation}

According to the reported literature, sweet sorghum for phytoremediation of $\mathrm{Cd}$ pollution indicates the following five special features:

Firstly, the $\mathrm{Cd}$ tolerance and bioaccumulation in sorghum plants varied greatly amongst different sorghum genotypes. Considering the vast genetic diversity of sorghum, the investigations on diverse sorghum accessions under $\mathrm{Cd}$ stress have been carried for germplasm screening, including 96 sorghum genotypes in hydroponic condition [76], 107 cultivars in hydroponic cultures and under field conditions [77], and 166 sorghum accessions in field tests [21]. Several promising sorghum cultivars 
were identified for restoring $\mathrm{Cd}$ contaminated areas, and Liu et al. [21] proposed that sorghums with different $\mathrm{Cd}$ accumulation properties could be applied for different end uses. More large-scale field experiments in different polluted environments are still needed to verify the phytoremediation capacity of sorghum varieties for tailored selection.

Secondly, sweet sorghum is not termed hyperaccumulator, but employed as high-biomass-producing non-hyperaccumulating plants for phytoremediation. So far, none of the sorghums has been reported meeting the Cd concentration threshold $(100 \mathrm{mg} / \mathrm{kg})$ in dry biomass of hyperaccumulator definition. High $\mathrm{Cd}$ pollution would seriously inhibit the growth of sweet sorghums, thus sweet sorghum phytoremediation is more suitable for moderate or low $\mathrm{Cd}$ pollution conditions $(\leq 30 \mathrm{mg} /$ $\mathrm{kg})[64,65]$. In low Cd-contaminated farmland and site near the abandoned mine, the abundant biomass reserves of sweet sorghums contributed to their Cd uptake, even making their $\mathrm{Cd}$ removal capacity quite competitive with many hyperaccumulators [20,22].

Thirdly, while the Cd concentration in the root is obviously higher than those in the aerial parts for sweet sorghum, total $\mathrm{Cd}$ removal is mainly achieved by aerial parts especially stems for their high yields. As non-hyperaccumulator, the translocation factor of sweet sorghum (shoot-to-root ratio of Cd concentration) is $<1$. Especially in short-term experiments cultivating sorghum seedlings under $\mathrm{Cd}$ stress, most of the absorbed $\mathrm{Cd}$ was still retained in the roots $[63,67$, 76]. During the sorghum growth period, $\mathrm{Cd}$ is continuously transported from the root to the aerial parts in a low concentration. As illustrated in Fig. 4a, the results of tracking $\mathrm{Cd}$ levels in sweet sorghum at different growth stages showed that $\mathrm{Cd}$ concentrations in different tissues consistently exhibited an order of (a)

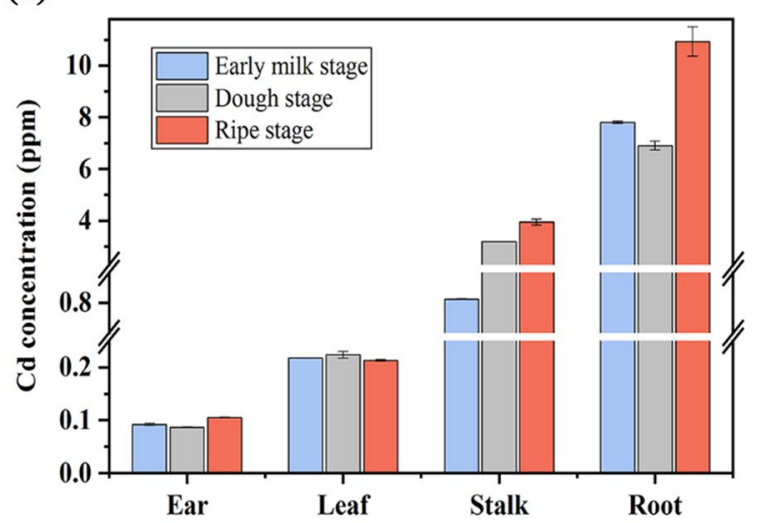

(c)

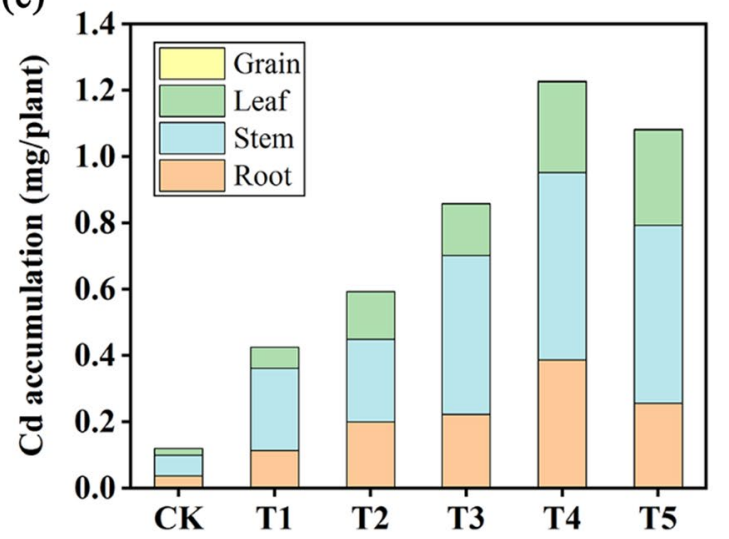

(b)

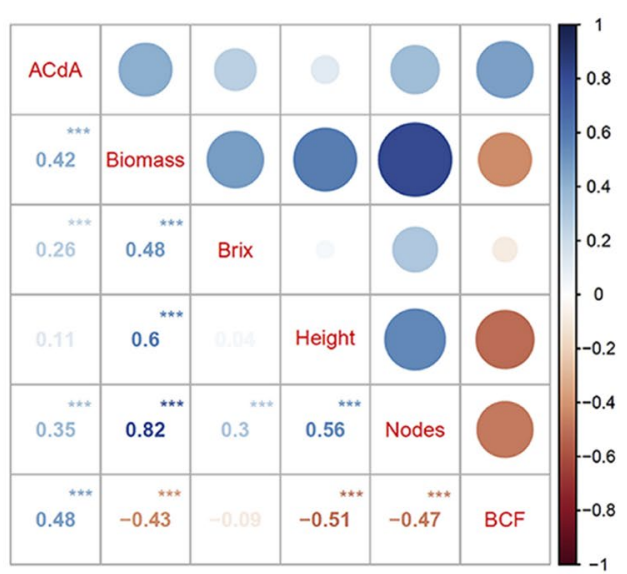

(d)

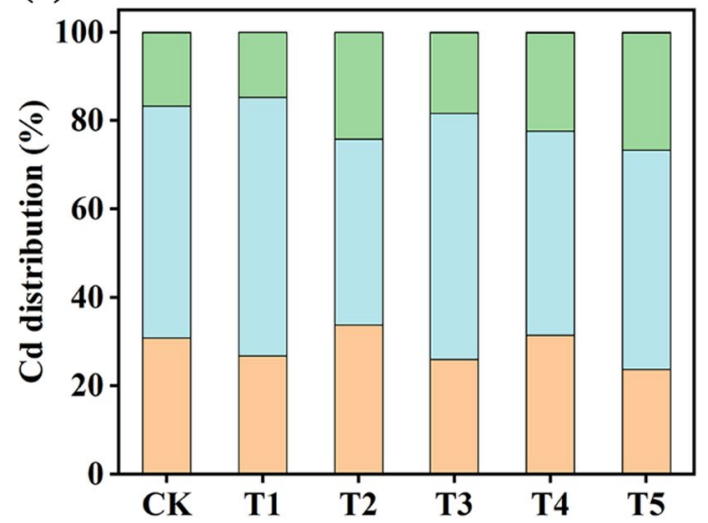

Fig. 4 Characteristics of sweet sorghum in Cd phytoremediation. a The Cd concentrations in different sorghum dried tissues. Adapted from [22], Elsevier B. V., Copyright (2021). b Pearson pairwise correlations among sorghum aboveground Cd accumulation (ACdA), the bioaccumulation factor (BCF), and bioenergy-related traits. Reprinted from [21], Elsevier B. V., Copyright (2020). The Cd accumulation (c) and distribution |(d) in the different organs of sweet sorghum (grown in soils with Cd concentrations of 0.25 (CK), 2.3 (T1), 5.9 (T2), 7.2 (T3), 18.1 (T4), and 33.6 (T5) for 167 days). Adapted from [71], with permission of the authors 
root $>$ stalk $>$ leaf $>$ ear. Specifically, it was observed that the $\mathrm{Cd}$ concentration in stalk increased substantially from the milk stage to the dough stage meanwhile in root decreased slightly [22]. Whereas, the proportion of root biomass in mature sweet sorghum is significantly small, causing the total $\mathrm{Cd}$ content in root lower than that in aerial parts $[65,71]$. Even under different concentrations of $\mathrm{Cd}$ contamination, the $\mathrm{Cd}$ within mature sweet sorghum mainly accumulated in the stalk (Fig. 4c), and the normalized results showed that stalks accounted for the largest proportion of total $\mathrm{Cd}$ at $42-58 \%$ (Fig. $4 d$ ) [71]. This feature reminds that the germplasm screening for phytoremediation sweet sorghum should take sorghums in different growth periods into consideration, instead of restricting the screening scope to seedlings.

Fourthly, the aboveground $\mathrm{Cd}$ accumulation ( $\mathrm{ACdA}$ ) is strongly associated with bioenergy-related agronomic traits of sorghum. Based on the agronomic traits of the sorghum accessions grown in a typical Cd-polluted field, Liu et al. [21] performed a Pearson pairwise correlation analysis to explore the possible factors influencing Cd uptake in sorghum (as shown in Fig. 4b). It has been identified that the ACdA is positively correlated with the biomass, internode numbers, stem Brix, and plant height, which are important bioenergy traits for sweet sorghum. The sweet sorghum accessions had higher $\mathrm{Cd}$ concentrations in aboveground organs than grain sorghum accessions by no accident. On the other hand, the bioaccumulation factor (BCF), i.e. the ratio of $\mathrm{Cd}$ concentration in the whole aboveground of sorghum to soil $\mathrm{Cd}$ concentration, was significantly negatively correlated with the bioenergy traits, except for Brix. It was inferred that there would be a dilution effect on the capacity for $\mathrm{Cd}$ accumulation in sorghum.
Finally, as herbaceous annual grass, sweet sorghum can be completely removed together with the roots after harvest every year to achieve an efficient and thorough phytoremediation effect. Bioenergy crops including Miscanthus, Pennisetum purpurem, and Arundo donax have also been reported to have the capacity to absorb and fix HMs [78-80]. However, they are deep-rooted perennial grasses, and $\mathrm{Cd}$ is primarily accumulated in their underground parts. On the one hand, they may not be in full production and do not fully develop their rhizomes or the root system for phytoremediation in the first year of planting [79]. On the other hand, their large underground organs are difficult to completely remove after years of planting, hence the heavy metals-containing remainder in soil will pose a continuous threat to the environment. Additionally, phytoremediation of Cd-polluted soil by woody plants such as Eucalyptus, Salix, and Populus carries many year-consuming and requires a high cost [81-83].

\subsection{Potential bioethanol yield of sweet sorghum under $\mathrm{Cd}$ stress}

Sweet sorghums grown in Cd-contaminated soil are not suitable for the production of food or feed, but offer a promising bridge between phytoremediation and bioethanol production (as shown in Fig. 5a). Previously, the bioethanol yield of sweet sorghum under $\mathrm{Cd}$ stress was roughly estimated based on plant dry weight in pot test and the theoretical ethanol production per hectare. It was predicted that sweet sorghum treated with $1,5,10,30$, 50 , and $100 \mathrm{mg} / \mathrm{kg} \mathrm{Cd}$ polluted soil could produce ethanol of 3.65, 3.05, 3.14, 2.69, 1.15 and $0.41 \mathrm{t} / \mathrm{ha}$, respectively (Fig. 5b) [65]. Furthermore, Liu et al. [21] chose to perform the theoretical calculation of ethanol yields from the cellulose, hemicelluloses, starch, and total soluble

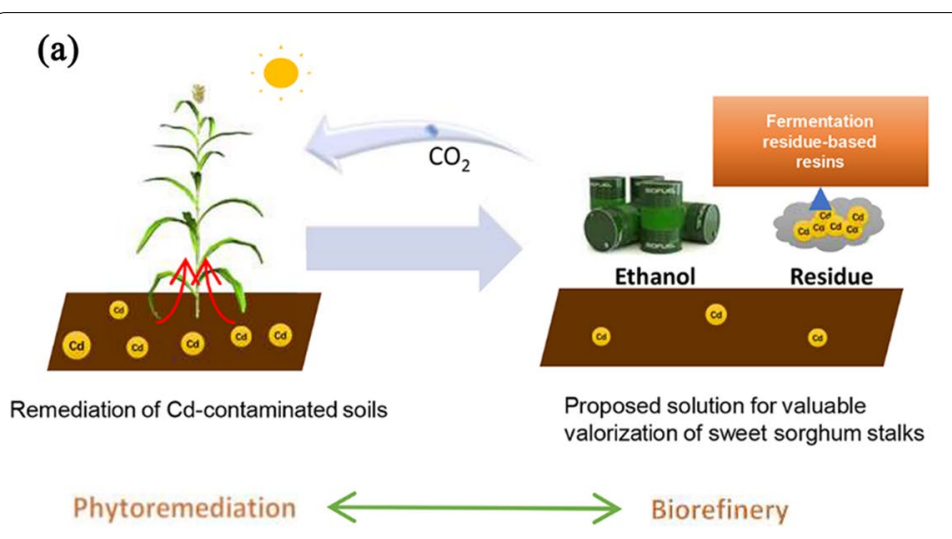

(b)

Fig. 5 Bioenergy potential of sweet sorghum for Cd-polluted soil phytoremediation. a Proposed strategy of using sweet sorghum integrated with phytoremediation and biorefinery. Reprinted from [22], Elsevier B. V., Copyright (2021). b Predicted removable Cd content and ethanol yield of sweet sorghum at different Cd concentration levels. Reprinted from [65], Taylor \& Francis Ltd (http://www.tandfonline.com), Copyright (2015) 
sugars contents in the five selected sorghum accessions. Assuming the sowing density of 165,000 plants/ha and double-cropping a year, sweet sorghum harvested from Cd-contaminated agricultural field $(2.80$ and $3.03 \mathrm{mg} / \mathrm{kg}$ $\mathrm{Cd}$ in soil) would produce 17.4-25.2 $\mathrm{t} / \mathrm{ha}$ ethanol in total. Specifically, Xiao et al. [22] comprehensively investigated the biomass yields of sorghums and the components of stalks under large-scale field planting with soil $\mathrm{Cd}$ concentration of 0.25 and $0.96 \mathrm{mg} / \mathrm{kg}$. The total theoretical bioethanol yields of sorghum stalks achieved 5510-7510 $\mathrm{L} / \mathrm{ha}(4.36-5.93 \mathrm{t} / \mathrm{ha}$ ) from one harvest. In addition, it has been reported that the stalks of sweet sorghum under Cd treatment $(2.34-33.6 \mathrm{mg} / \mathrm{kg})$ could be utilized by advanced solid state fermentation technology and presented no effect on sugar utilization rate as well as ethanol conversion rate during fermentation [71]. From the above, it is probable to pursue both environmental safety and energy benefits adopting phytoremediation sweet sorghum.

\section{Bioethanol production from SSS}

SSS is a good feedstock containing abundant soluble sugars and lignocellulosic biomass for $1 G$ and $2 G$ bioethanol production respectively (as demonstrated in Fig. 6). The production of sugar-based bioethanol can be directly achieved via microorganism fermentation, while the lignocelluloses require the pretreatment as well as the saccharification and hydrolysis strategies for $2 \mathrm{G}$ bioethanol production [24]. In this part, the bioethanol production from SSS will be discussed from three aspects: soluble sugars, sweet sorghum bagasse (SSB), and straw.

\subsection{Soluble sugars to bioethanol}

Most SSS contain approximately $15-40 \%$ soluble sugars on a dry mass basis, with some varieties containing up to $50 \%$ soluble sugars, primarily sucrose, glucose, and fructose [34, 85-92]. The total soluble sugar contents and the respective proportions of sucrose, fructose, and glucose in SSS are determined by genotype, planting year (environment), and phenological stage [49, 92-97]. In order to acquire the fermentable soluble sugars, the traditional and the most common approach is to mechanically press the stalks to release the saccharine juice. However, the crushing process is labor and energy intensive, and the juice recoveries of sweet sorghum from normal roller mills are generally below $60 \%$ [32, 98, 99]. Compared with sugarcane, the leaves left on stalks as well as the comparatively high contents of fiber and pith of sweet sorghum will limit the juice extraction yields and purities [100]. Additionally, the juice spoilage resulting from contaminating bacteria throughout storage and the juice clarification are also two significant issues [101]. For full utilization of the soluble sugars, other approaches have also been developed such as diffusion methods and solid state fermentation (SSF).

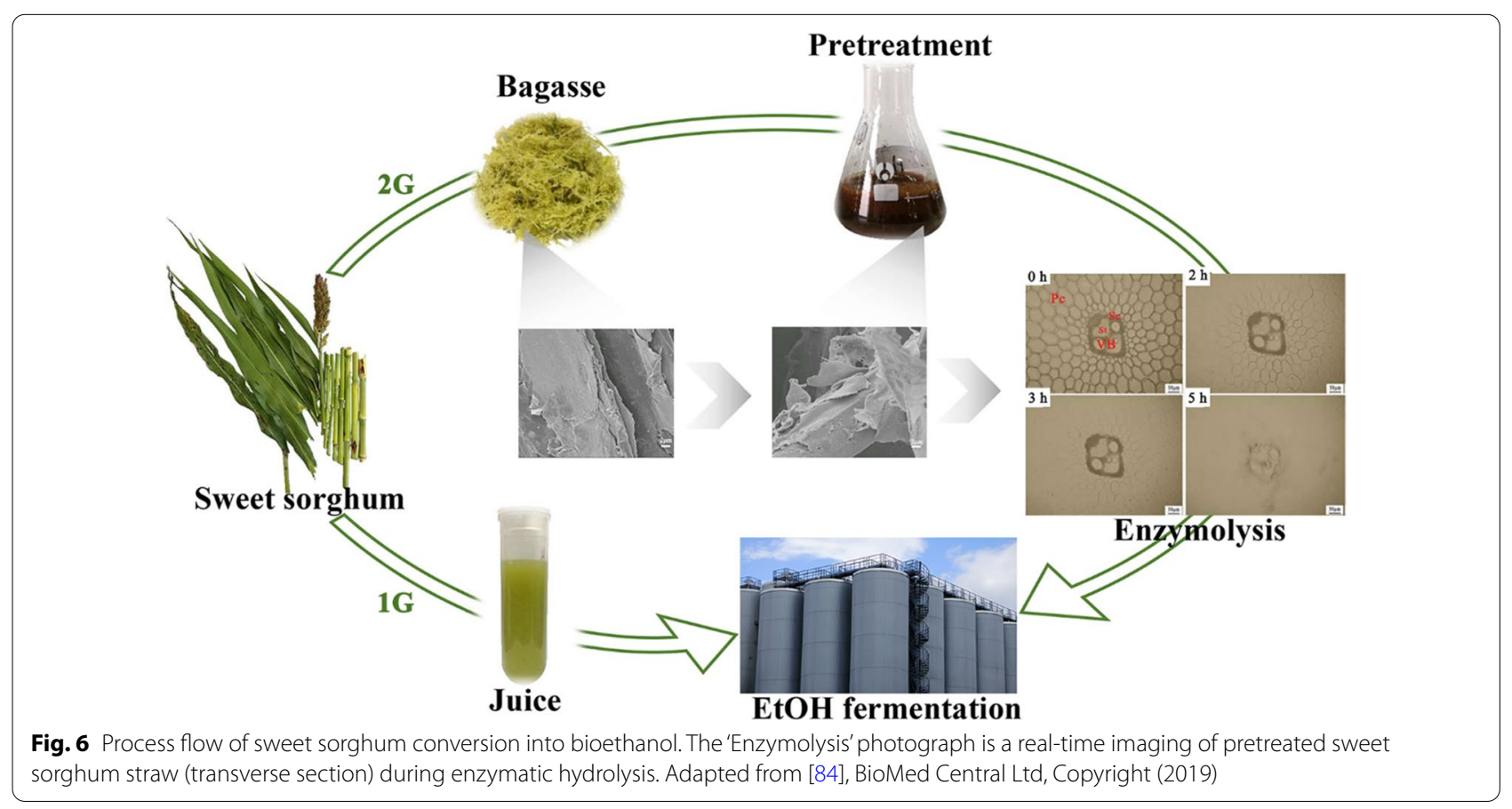




\subsubsection{Liquid state fermentation}

Contents of total soluble sugars in sweet sorghum juices are in the range of $110-190 \mathrm{~g} / \mathrm{L}$ [98, 99, 102-106]. The fermentation of juices to ethanol has been extensively studied and established, and yeast (Saccharomyces cerevisiae) fermentation is the principal mechanism, that can efficiently convert sugars to ethanol under anaerobic conditions. As demonstrated in Table 2, yeast fermentation is capable to reach ethanol yields higher than $90 \%$ of the theoretical value, and the optimal fermentation temperature is around $30{ }^{\circ} \mathrm{C}$, with the expected $\mathrm{pH}$ range of 4.0-5.2. The engineered microorganisms Escherichia coli could also be used for sweet sorghum juice fermentation, but with poor performance in sucrose utilization [105].

The laboratory-scale fermentation studies performed as liquid batch fermentation have evaluated the performance of sweet sorghum juices in ethanol fermentation, reaching up to the best fermentation efficiency of $94 \%$ $[98,99]$. Fed-batch fermentation has been introduced to avoid the repressive effects of high product concentration and increase the conversion efficiency [102]. Continuous fermentation may minimize the concentration of inhibitory compounds, but the long cultivation times pose a high risk of outside contamination [100]. The repeatedbatch fermentation is proposed as an extension, which drains the fermented juice at regular intervals and reuses the yeast cells recovered from the preceding fermentation broth for the next batch. This process offers many benefits including eliminating the costly re-sterilization steps and no requirement of inoculum preparation, leading to an enhancement in ethanol productivity. Besides, repeated-batch fermentation is able to use the sweet sorghum juice concentrated by the membrane separation system without any addition of exogenous nutrients [107-110]. To avoid the reduction in yeast cell concentration in repeated-batch process, the immobilized yeast cell systems are developed. Ethanol fermentations by immobilized yeast from stalk juice of sweet sorghum were effective, and the application of fluidized bed reactor significantly shortened the fermentation time [111, 112]. Considering the instability and high cost of conventional immobilization methods (cell entrapment on $\mathrm{k}$-carrageenan or $\mathrm{Ca}$-alginate), porous natural lignocellulosic materials such as corncob and SSS were employed as the carriers for cell immobilization, achieving high ethanol yields in sweet sorghum juice fermentation [113, 114]. Very high gravity (VHG) fermentation produces ethanol from mashes containing at least $250 \mathrm{~g} / \mathrm{L}$ sugars with high productivity, therefore it has been described as "productive, water-saving, and cost-effective technology". Under appropriate aeration and nutrient supplementation in VHG conditions, the maximum ethanol concentration and yield in sweet sorghum juice fermentation could reach over $120 \mathrm{~g} / \mathrm{L}$ and $99 \%$. In addition, the high osmotic conditions will reduce the risk of bacterial contamination [115-117].

Diffuser extraction is a common technology in the sugar industry that typically achieves greater sugar extraction efficiency than juice extraction by crushing. In the cane sugar industry, diffusers can recover up to

Table 2 Summary of literatures on sweet sorghum juice fermentation

\begin{tabular}{|c|c|c|c|c|c|c|c|c|}
\hline \multirow[t]{2}{*}{ Fermentation mode } & \multirow[t]{2}{*}{ Microorganisms } & \multirow{2}{*}{$\begin{array}{l}\text { Fermentation } \\
\text { conditions }\end{array}$} & \multirow[t]{2}{*}{ Time (h) } & \multirow{2}{*}{$\begin{array}{l}\text { Initial total } \\
\text { sugar (g/L) }\end{array}$} & \multicolumn{3}{|l|}{ Ethanol } & \multirow[t]{2}{*}{ References } \\
\hline & & & & & $P(g / L)$ & $Q_{p}(g / L / h)$ & Yield (\%) & \\
\hline \multirow[t]{3}{*}{ Batch } & $\begin{array}{l}\text { Alcohol yeast Ethanol } \\
\text { Red }\end{array}$ & $\mathrm{pH} 4.2,30^{\circ} \mathrm{C}, 150 \mathrm{rpm}$ & 72 & 200 & - & - & $93-94$ & [99] \\
\hline & Baking yeast & $\mathrm{pH} 4.5,30^{\circ} \mathrm{C}, 100 \mathrm{rpm}$ & 24 & $110-191$ & $43-82$ & - & $68-94$ & {$[98]$} \\
\hline & S. cerevisiae JP1 & $\mathrm{pH} 4.5,37^{\circ} \mathrm{C}, 200 \mathrm{rpm}$ & 11 & 162 & 72 & 6.5 & 87 & {$[104]$} \\
\hline Fed-batch & S. cerevisiae TISTR 5048 & $\mathrm{pH} 4.8,30^{\circ} \mathrm{C}$, static & 108 & 240 & 120 & 1.11 & 94 & {$[102]$} \\
\hline \multirow[t]{4}{*}{ Repeated-batch } & S. cerevisiae SSJKKU01 & $\mathrm{pH} 4.0,32^{\circ} \mathrm{C}, 200 \mathrm{rpm}$ & 231 (8 cycles) & $180-217$ & 105 & 2.16 & 84 & {$[107]$} \\
\hline & S. cerevisiae BY4741 & $\mathrm{pH} 5.2,30^{\circ} \mathrm{C}, 35 \mathrm{rpm}$ & $5 * 48$ & 270 & 114 & 2.37 & 89 & {$[108]$} \\
\hline & S. cerevisiae BY4741 & $\mathrm{pH} 5.2,30^{\circ} \mathrm{C}, 35 \mathrm{rpm}$ & $5 * 24$ & 228 & $102-110$ & - & $84-90$ & {$[109]$} \\
\hline & S. cerevisiae F118 & $\mathrm{pH} 5.2,30^{\circ} \mathrm{C}, 150 \mathrm{rpm}$ & $5 * 24$ & 188 & 100 & 4.18 & $69-79$ & {$[110]$} \\
\hline \multirow{2}{*}{$\begin{array}{l}\text { Immobilized yeast } \\
\text { fermentation }\end{array}$} & S. cerevisiae CICC 1308 & $\mathrm{pH} 5.0,37^{\circ} \mathrm{C}, 200 \mathrm{rpm}$ & 11 & 69 & 33 & 3.0 & 93 & {$[111]$} \\
\hline & S. cerevisiae Nanyang & $\mathrm{pH} 4.0,32^{\circ} \mathrm{C}, 150 \mathrm{rpm}$ & 5 & 111 & 49 & - & 92 & {$[112]$} \\
\hline \multirow{2}{*}{$\begin{array}{l}\text { Immobilized yeast in } \\
\text { repeated-batch }\end{array}$} & S. cerevisiae TISTR 5048 & $\mathrm{pH} 4.0,30^{\circ} \mathrm{C}$, static & $8 * 48$ & 240 & 97 & 2.02 & 94 & {$[113]$} \\
\hline & S. cerevisiae NP01 & $\mathrm{pH} 4.0,30^{\circ} \mathrm{C}$, static & $8 * 72$ & 230 & 99 & 1.36 & 92 & {$[114]$} \\
\hline \multirow[t]{2}{*}{ Very high gravity } & S. cerevisiae NP01 & $\mathrm{pH} 4.9,30^{\circ} \mathrm{C}$, static & 60 & 286 & 121 & 2.01 & 99 & {$[115]$} \\
\hline & S. cerevisiae NP01 & $\begin{array}{l}\text { No pH adjustment, } \\
30^{\circ} \mathrm{C}, 100 \mathrm{rpm}\end{array}$ & 60 & 280 & 126 & 2.11 & 98 & {$[116]$} \\
\hline
\end{tabular}

* $\mathrm{P}$, ethanol concentration; $\mathrm{Q}_{p}$, volumetric ethanol productivity 
$98 \%$ of the sugar while requiring simpler operation and maintenance, lower energy consumption, and lower costs than milling [100, 118]. In the diffusion process, raw materials are reduced to uniform geometric size and then passed through a series of gradient solutions that dissolved molecules [119]. The nonstructural carbohydrates in SSS can be easily extracted by water, and it has been reported that the water extraction recovered 2.5 times more sugar mass from SSS than press juice $[89,120]$. The diffusion extraction method is applicable to both fresh SSS and dried ones, as well as to sorghum bagasse [121]. The extracted sugar solution can be fermented in liquid state as sweet sorghum juice, and would not impact the fermentation efficiency. Moreover, the liquid could even be incorporated into the dry-grind ethanol process or hemicellulosic sugar streams obtained through the steam treatment to enhance bioethanol yields [90, 120, 122]. A diffusion process is reported combining the utilization of starch in the panicles and soluble sugars in the stalks of sweet sorghum, realizing the high efficiencies for starch conversion (96\%) and sugar recovery (98.5\%) [119].

\subsubsection{Solid state fermentation (SSF)}

SSF has been defined as the bioprocess carried out in the absence, or near-absence of free water, involving the growth and metabolism of microorganisms on solid matrix [123]. Contrary to liquid state fermentation, the SSF of stalks directly converts the free sugars to ethanol, skipping the juice squeezing or sugar extraction. The SSF technology has continued to build up credibility in fuel ethanol production from sweet sorghum due to its higher sugar utilization and ethanol yield, lower energy expenditure and capital cost, and reduced water usage and wastewater output [124]. Previous studies explored the bioethanol production from fresh SSS or dry stalk particles by static SSF in laboratory scale, while investigating the influence of diverse process parameters such as particle size, yeast inoculation rate, temperature, and moisture content. And the maximum ethanol yields of 7.9 g-ethanol/100 g-fresh stalk and 0.25 g-ethanol/g-dry stalk were obtained [125-127]. Various thermotolerant yeasts are frequently used in SSF for sweet sorghum ethanol production, such as yeast AF37X [125], Issatchenkia orientalis IPE 100 [127], and S. cerevisiae TSH3 [128], while zygomycetes fungus Mucor indicus could also be an option [85].

Nevertheless, the absence of free water during SSF leads to poor heat removal, posing serious mass and heat transfer challenges for the industrial-scale operation of SSF. Other challenges including high viscosity, difficulty in fermentation control and solid handling, and limited types of microorganisms also impede large-scale production [41]. To achieve a cost-effectively system for commercial bioethanol production from SSS, advanced solid-state fermentation (ASSF) technology has been established and continuously improved. A rotary drum fermentation reactor was specially designed for efficient mass control and heat transfer; a Saccharomyces cerevisiae strain TSH-SC-1 with preeminent ethanol fermentative capacity and ability to withstand stressful SSF conditions was identified; the distillation kinetics in batch solid-state distillation to extract ethanol from fermented sweet sorghum bagasse was investigated [41, $124,129,130]$. A commercial demonstration scale 550$\mathrm{m}^{3}$ rotary-drum fermentation system has already been constructed, fermenting up to 96 tons of crushed sweet sorghum within $20 \mathrm{~h}$ [124]. Besides, the ASSF technology could be combined with the alkaline pretreatment of sweet sorghum bagasse and C5-C6 co-fermentation in a whole process, and $91.9 \mathrm{~kg}$ ethanol/ton fresh SSS would be obtained under optimal conditions [131-133].

\subsection{SSB to bioethanol}

Sweet sorghum bagasse (biomass residue after juice extraction) is a promising feedstock for $2 \mathrm{G}$ bioethanol production, which primarily consists of cellulose, hemicelluloses, and lignin as illustrated in Fig. 7a. The raw SSB also contains some residual soluble sugar fraction (25-29\%), and hot-water washing is an effective recovery method [121, 134, 135]. For the production of ethanol from SSB, cellulose and hemicelluloses must be disassembled into their corresponding pentose and hexose sugars before fermentation. However, the intricate structure of lignocellulosic biomass generates recalcitrance to chemicals or enzymes, resulting in critical challenge in the conversion processes of bioethanol [136]. The crucial factors affecting the biomass enzymatic digestibility include cellulose fiber crystallinity (CrI), sheathing and protection of both hemicelluloses and lignin, and porosity [137, 138]. Therefore, the SSB needs to be subjected to an effective pretreatment process to reduce the crystallinity, alter or remove hemicelluloses and lignin, and increase the accessible surface area to enzyme. The methods reported for the pretreatment of SSB can be categorized as physical (e.g. mechanical crushing, milling, irradiation, and sonication); chemical (e.g. acid, alkaline, peroxide, organic solvents, and ionic liquids); physico-chemical (e.g. hydrothermal treatment and steam explosion); biological; and other combined approaches. Besides, the pith and rind parts of sorghum stem are composed of different cell types, leading to the heterogeneity in chemical composition and biomass recalcitrance [139]. Furthermore, the cuticular waxes from sweet sorghum stem could inhibit the fermentation of acetone-butanol-ethanol to a certain extent [140]. To improve the utilization of sorghum stems, appropriate processing may be required to 

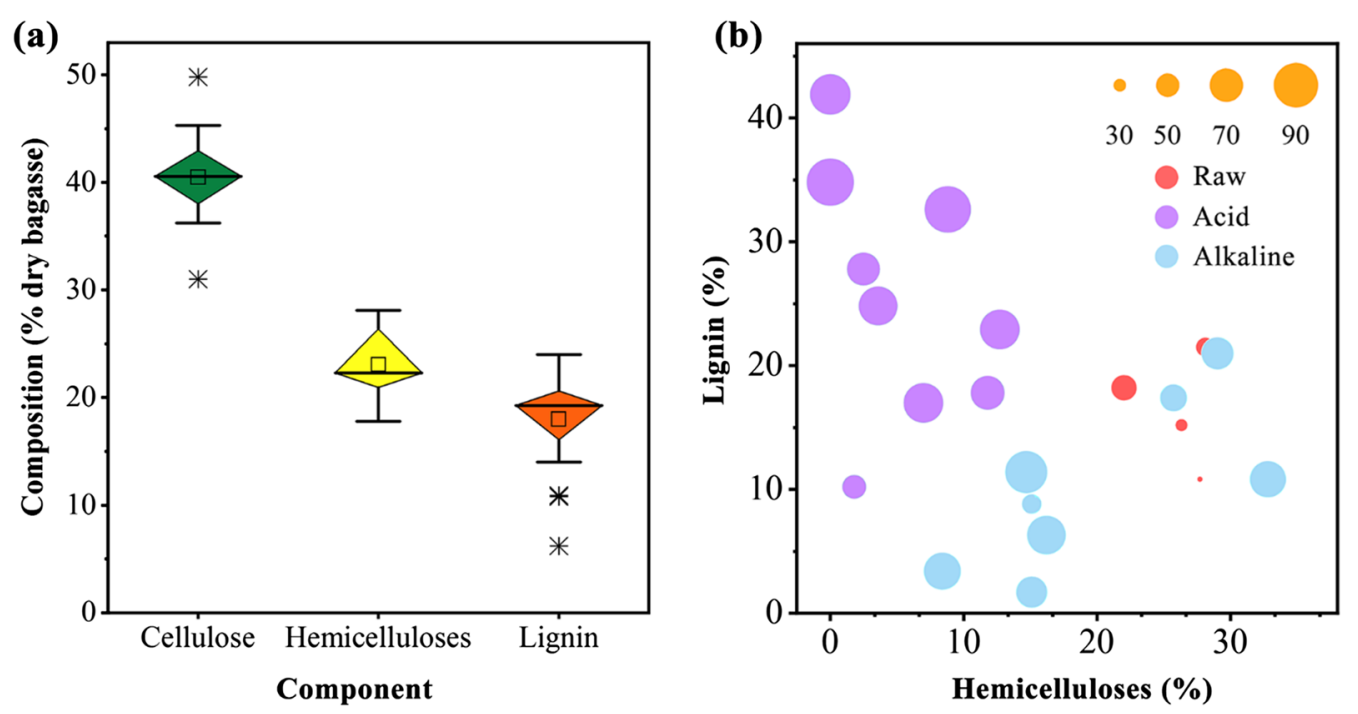

Fig. 7 Chemical composition and pretreatment effects of sweet sorghum bagasse. a Variations of components of dry bagasse [84, 93, 103-106, $121,132,141-152]$. b Effects of acid/alkali pretreatments on the removals of hemicelluloses and lignin, and the ethanol yields of pretreated SSB [84, $104,106,132,141,143,144,146,147,149,150,152,153]$. The area of the circle represents the corresponding percentage to the theoretical ethanol yield. Partial ethanol yields were estimated based on the cellulose hydrolysis yields and enzymatic hydrolysis efficiencies

eliminate the negative effects caused by the rind region in bioethanol production.

\subsubsection{Physical pretreatment}

The physical or mechanical treatment is the first step for biorefinery processing. Methods such as chipping, milling, and grinding can be applied to effectively reduce the particle size of SSB, and also contribute to the reduction of cellulose crystallinity as well as the degree of polymerization (DP) [45, 138]. Particle size reduction increases the surface area and alleviates physical hindrances of raw biomass, thereby improves the subsequent pretreatment effect, enzyme accessibility, and the efficiency of enzymatic hydrolysis [26, 154]. Nevertheless, the comminution process of lignocelluloses is energy intensive, hence the processing needs to be considered with both biomass characteristics and the final particle size required [138]. Other forms of physical techniques such as ultrasonic [155], microwaves [135, 154], heavy ion beams irradiation [156], and gamma rays [157] have also been experimented for sweet sorghum pretreatment. However, there is no doubt that these methods will be costly to use on a large scale, along with the security risks.

\subsubsection{Chemical pretreatment}

Some chemicals are applied to pretreatment for efficient destruction of the native lignocellulosic structure and piercing the shields composed of lignin and hemicelluloses. The processes and pretreatment effects of recently reported chemical pretreatments of SSB are listed in
Table 3. Indeed, SSB can be directly acid hydrolyzed into C5 and C6 sugars under relatively high acid concentration and long hydrolysis time treatments, but the sugars would also degrade into inhibitors under these harsh conditions and cause carbohydrates loss [158]. Therefore, the most established and common method for SSB producing bioethanol is pretreatment with dilute acids or alkalis under relatively mild conditions followed by enzymatic digestion.

Based on the previous research results, the effects of acid/alkaline pretreatments were visualized as Fig. 7b. While the mechanisms of the two pretreatment approaches are different, both are effective in improving the accessibility of cellulose and thus enzymatic efficiency. In acid pretreatment, $\mathrm{H}_{2} \mathrm{SO}_{4}, \mathrm{HCl}, \mathrm{CH}_{3} \mathrm{COOH}$, and $\mathrm{H}_{3} \mathrm{PO}_{4}$ are generally exercised for hemicelluloses hydrolysis [143, 148-150]. Meanwhile, the xylan solubilization during acid pretreatment causes the collapse and porosity on the surface of the originally compact SSB fibers $[84,159]$. On the other hand, alkaline (e.g. $\mathrm{NaOH}$, $\mathrm{Ca}(\mathrm{OH})_{2}$, and $\left.\mathrm{NH}_{3} \cdot \mathrm{H}_{2} \mathrm{O}\right)$ pretreatment can cleave the ester bonds, weaken the hydrogen bond between hemicelluloses and cellulose, and lead partial lignin and hemicelluloses in the SSB removed, thereby getting rid of the lignin barriers and increasing the porosity of the biomass [84, 144, 146, 153].

Other chemical pretreatments such as $\mathrm{H}_{2} \mathrm{O}_{2}$, ionic liquids [BMIM] Cl, glycerol, 1-butanol were also feasible for sorghum bagasse, but their process costs are expensive $[84,141,153,160]$. Simulated green liquor pretreatment 


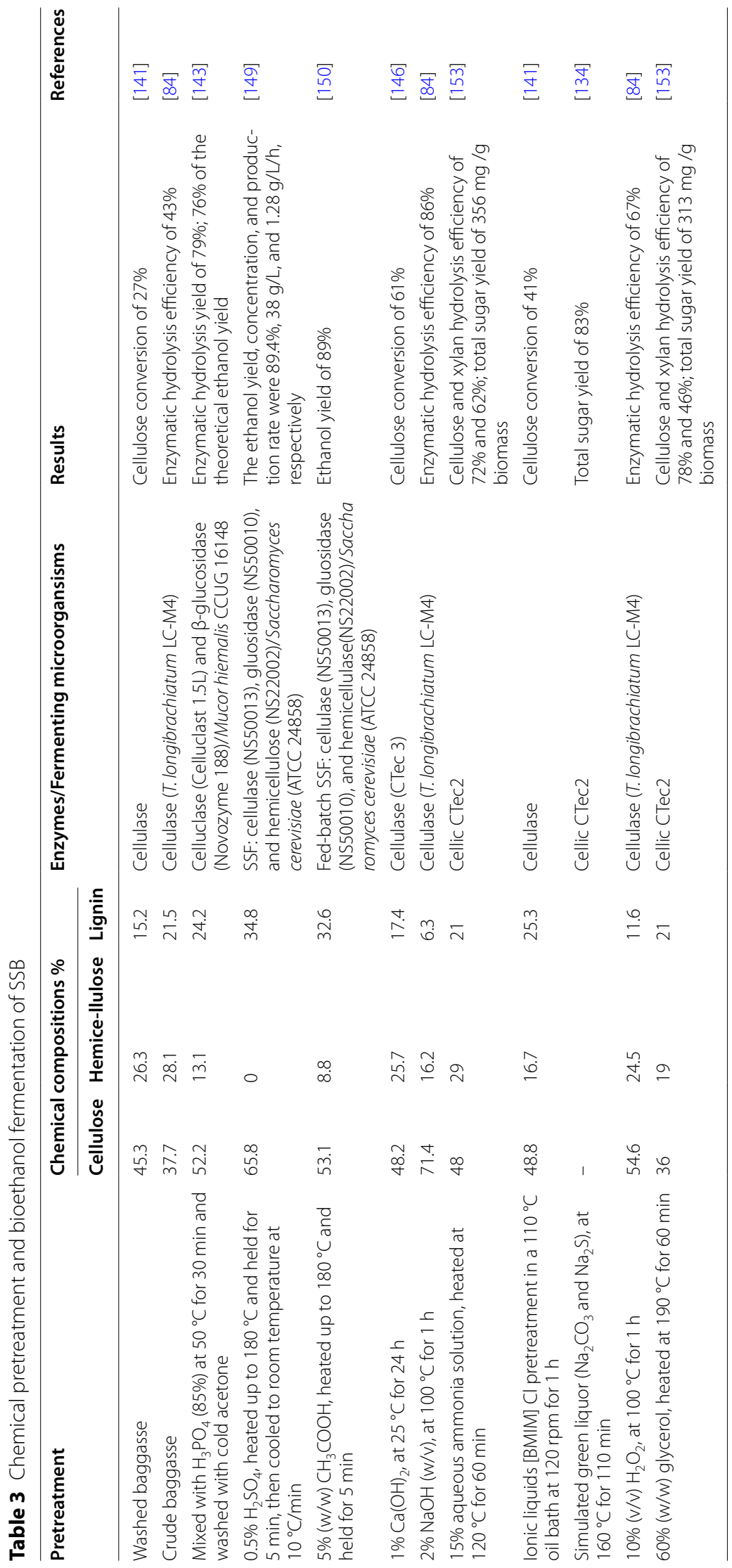


$\left(\mathrm{Na}_{2} \mathrm{CO}_{3}\right.$ and $\left.\mathrm{Na}_{2} \mathrm{~S}\right)$ on SSB could dissolve lignin while preserving carbohydrates. As a result, the predicted total sugar yield could reach $83.2 \%$ at optimum condition $\left(160{ }^{\circ} \mathrm{C}\right.$ for $110 \mathrm{~min}$, liquid/solid ratio of 7 , total titratable alkali of $18 \%$, and sulfidity of $40 \%$ ) [134]. Still, chemical pretreatments have some disadvantages, such as the equipment requirement, carbohydrate loss, generation of toxic chemicals, and relative high cost.

\subsubsection{Physico-chemical pretreatment}

Physical-chemical pretreatment of SSB is mainly achieved by liquid hot water (LHW) pretreatment, steam explosion, and ammonia fiber explosion (AFEX). Comparing with chemical methods, the LHW pretreatment with no chemical addition and little erosion on equipment is becoming attractive. During the LHW pretreatment, the hemicelluloses can be well solubilized with the majority of pentosan recovered, while avoiding the generation of fermentation inhibitors. Simultaneously, liberation of acids during hemicelluloses hydrolysis and the minor loss of cellulose would enhance the following enzymatic hydrolysis [121, 161, 162]. After pretreatment with LHW at a step-change flow rate $\left(184^{\circ} \mathrm{C}\right.$ for $8 \mathrm{~min}$ at $20 \mathrm{~mL} / \mathrm{min}$, then $10 \mathrm{~min}$ at $10 \mathrm{~mL} / \mathrm{min}$ ) and $72 \mathrm{~h}$ enzymatic digestion, the SSB could produce $83.7 \%$ of the total sugars [161]. Steam treatments of SSB can be performed with or without catalyst, which heat biomass by saturated steam and then decompress the pressured system to achieve an explosion effect. This process allows a better fractionation of SSB and solubilization of hemicellulose and even lignin $[89,105,138,163]$. Zhang et al. [141] revealed that the steam-exploded SSB attained the maximum cellulose conversion of $70 \%$, which was about 1.6 times higher than that of the untreated sample (27\%). Li et al. [164] optimized the AFEX pretreatment for SSB (120\% moisture content, 2:1 ammonia to biomass loading, $140{ }^{\circ} \mathrm{C}$, and $30 \mathrm{~min}$ residence time), and achieved the glucan and xylan conversion about $80 \%$ and $90 \%$, respectively.

\subsubsection{Biological pretreatment}

As the most similar to the natural conversion route of lignocellulosic biomass, biological pretreatment commonly represents eco-friendly. In biological pretreatment, fungi are the most suitable and efficient candidates, which produce enzymes that can degrade hemicelluloses, lignin, and polyphenols efficiently. Besides fungi, some microbial consortium, bacterial systems, and crude enzymes such as lignin peroxidases, Mn peroxidase, and laccases are also applied to destruct the lignocellulosic biomass. Whereas, the biological approach is generally slower and has lesser efficiency than other pretreatments for industrial purposes [45, 138]. Latterly, Mishra et al. [165] found that fungus Coriolus versicolor could pretreat the SSB selectively due to its high ligninolytic and low cellulolytic enzyme production. In addition, the maximum lignin degradation was achieved with syringic acid supplement, resulting in a 1.9 times higher sugar yield than untreated SSB.

\subsubsection{Combined approaches}

The mixture of one or more pretreatment methods are also applied for SSB pretreatment, such as physical-biological, chemical-physical, chemical-biological, and thermal-chemical pretreatments [45, 154, 166, 167]. Besides, there are also studies using multi-step chemical methods for pretreatment of SSB [144, 147, 152, 168]. Koo et al. reported a modified two-stage autohydrolysis combined with mechanical treatment, achieving the total sugar recovery of $83.9 \%$ to the total available sugars in SSB [121]. The selection of the pretreatment method should aim at minimizing additional energy consumption and having good compatibility with the next operation [169]. Nevertheless, the implementation of several, dissimilar pretreatment methods usually introduces additional requirements and costs, which is not desirable. Comprehensive consideration of pretreatment effect and cost is more conducive to industrial promotion and application.

\subsection{Stalk to bioethanol}

Traditional pretreatments such as acid and alkaline processes would decrease bioethanol yields of SSS since the degradation of free sugars. Recently, new approaches are developed to pretreat SSS in one step, thus avoiding the necessity of juice extraction. Nozari et al. [88] proposed an improved organosolv pretreatment for the bioconversion of SSS into bioethanol and biogas. The maximum gasoline equivalent $(0.249 \mathrm{~L} / \mathrm{kg})$ was obtained when using the mixture of $\mathrm{EtOH}$ and isopropanol (IPOH) (60:20) in the presence of $1 \% \mathrm{H}_{2} \mathrm{SO}_{4}$ treated SSS at $140{ }^{\circ} \mathrm{C}$ for 30 min. Damay et al. [170] put forward a novel approach based on steam pretreatment to recover the free and hemicellulosic monomeric carbohydrates from fresh sweet sorghum in one stage. Under the optimal operating conditions $\left(180^{\circ} \mathrm{C}\right.$ for $\left.3 \mathrm{~min}\right), 30 \%$ monomeric carbohydrates were recovered based on the dry weight of sorghum with the lowest composition of inhibitors. And the recovered carbohydrate streams achieved a maximum ethanol yield of above $95 \%$. Williams et al. [87] have firstly investigated the integration of soluble sugar extraction and mild $\mathrm{NaOH}$ pretreatment using counter-current solid-liquid extraction technology, and developed a novel processing scheme utilizing both extractable and structural carbohydrates to produce biofuels. The integrated deconstruction and extraction were conducted under alkaline conditions, employing the pretreatment 
with the equivalent of $0.06 \mathrm{~g} \mathrm{NaOH} / \mathrm{g}$ biomass at $80^{\circ} \mathrm{C}$ as one of the stages during counter-current extraction. The high $\mathrm{pH}(>12)$ liquor from the pretreatment stage was progressively neutralized over the subsequent extraction stages, finally dropping to an appropriate $\mathrm{pH}$ of 5.5. The mixed sugar solution of the extraction liquor and cellulosic hydrolysate was found to be fermentable without detoxification. A high bioethanol titer of $80 \mathrm{~g} / \mathrm{L}$ could be achieved by fermenting concentrated sugar stream.

\section{Screening and breeding of ideotypes}

World collection of sorghum consists of 235,711 accessions, exhibiting huge genetic diversity and resources towards the variations in climatic conditions of different regions [31, 171]. Conventional breeding techniques such as hybridization-based methods are successful in improving sorghum varieties [172]. With recent developments of sorghum research in the field of molecular biology, including the survey of mutant populations, dissection of quantitative trait loci (QTLs), identification, and isolation of genes controlling important agronomic traits, the process of molecular breeding is promoted [31]. DNA marker technologies and genetic transformation techniques are now increasingly employing for sorghum improvement to supplement traditional breeding methods [173, 174]. Previously, a suite of biofuel-related traits and their genetic determinants in sweet sorghum were identified, such as sugar content in stems, plant height, flowering time (maturity), plant architecture (leaves, root, and stem), and biomass bioconversion efficiency. Targeted genetic modulation can operate on these traits and pose a potential pathway to optimize sweet sorghum for biofuel production $[175,176]$.

For the optimum results of phytoremediation and bioethanol production, the screening and breeding of sweet sorghum ideotypes is a cornerstone. This targeted breeding aim requires for high $\mathrm{Cd}$ uptake, high biomass, high carbohydrates yield, and good adaptability to diverse agroclimatic conditions. As discussed in the above section on characteristics of sweet sorghum in Cd phytoremediation, the total $\mathrm{Cd}$ removal is mainly achieved by stems due to their high yields. Therefore, cultivars with high $\mathrm{Cd}$ translocation factor and stalk yields are more suitable for $\mathrm{Cd}$ removal. Besides, considering the strong correlation between bioenergy-related agronomic traits and aboveground $\mathrm{Cd}$ accumulation of sorghum [21], the screening of traits such as biomass, internode numbers, stem Brix, and plant height will be of substantial assistance. Feng et al. [67] reported that many DEGs relating to differential $\mathrm{Cd}$ accumulation in sweet sorghum were found to be linked with cell wall modification, including genes involved in cell wall biogenesis and modification as well as cell wall macromolecule (pectin, cellulose, lignin, and suberin) catabolic process. Additionally, partial MicroRNAs and their target genes of sweet sorghum that might function in $\mathrm{Cd}$ accumulation have been revealed [68]. These findings provide useful references for improving phytoremediation ability of sweet sorghum through genetic engineering.

A previous study showed that the SSB had a relatively higher biomass enzymatic digestibility than Miscanthus and wheat species. It also demonstrated that the arabinose substitution degree of the non- $\mathrm{KOH}$-extractable hemicelluloses in sweet sorghum exhibited a negative correlation with the raw material CrI, while also positively affected biomass enzymatic digestibility [91]. These results are highly probable to be related to the cell wall structure of sorghum. A unique model of sorghum cell wall architecture has been proposed that xylan in sorghum secondary cell walls is mainly in a three-fold screw conformation due to dense arabinosyl substitutions, with close interacting with amorphous cellulose but rarely docking on the hydrophilic surface of crystalline cellulose. Besides, sorghum secondary cell walls have a larger proportion of amorphous cellulose relative to dicots. Compared with the xylan-cellulose interactions in dicot plants and softwoods which are dominated by hydrogen bonds between two-fold screw xylan and cellulose fibrils on the hydrophilic surface, those in sorghum secondary cell walls dominated by interactions between the amorphous cellulose and three-fold screw xylan are significantly weaker [177]. These discoveries could offer fundamental guidance for genetic modification of plant cell walls oriented to reduce biomass recalcitrance and improve the bioenergy conversion efficiency of sweet sorghum.

\section{Conclusions and perspectives}

Sweet sorghum is a resilient and fast growing $\mathrm{C}_{4}$ plant, with a wide adaptability to different environmental conditions and relatively lower agronomic requirements. It can produce high biomass with abundant soluble sugars in the stalk, making a promising feedstock for bioethanol production. Although sweet sorghum is not hyperaccumulator, it can grow normally and produce adequate biomass under moderate $\mathrm{Cd}$ pollution. After maturity, most of the absorbed $\mathrm{Cd}$ is maintained in the aerial parts especially stems that can be removed entirely for bioethanol production, thus entering the energy chain rather than the food chain. Therefore, phytoremediation of Cd-polluted arable lands by sweet sorghum is a costeffective and ecofriendly pathway. Despite the achievements already made, some essential issues still exist and demand for emphasis.

In terms of the phytoremediation with sweet sorghum, the existing pot tests and field trials show that 
different sweet sorghum cultivars exhibit huge diversities in Cd tolerance and biofuel-related traits. Therefore, screening and selection of appropriate sweet sorghum varieties with high $\mathrm{Cd}$ absorption capability, high bioethanol yield, and superior adaptability to diverse agroclimatic conditions are extremely significant for practical application. Besides, the mechanism of $\mathrm{Cd}$ tolerance in sorghum remain not completely clarified, which requires more multidimensional and in-depth studies to figure out.

As for the further utilization of SSS after phytoremediation, the technology for the complete processing of bioethanol production is not well developed. Most published studies were conducted on a laboratory scale. Further research should strengthen the comprehensive use of sweet sorghum, integrate the $1 \mathrm{G}$ and $2 \mathrm{G}$ bioethanol production, and increase sharing of existing critical factory facilities, with the goal of minimizing investment and enhancing economic feasibility. It is extremely important that $\mathrm{Cd}$ is one of the most mobile HMs in the environment. Since there is still a serious gap of safe biorefining of $\mathrm{Cd}$-containing raw materials left to be filled, research on the migration pattern of $\mathrm{Cd}$ and the ultimate treatment should be expanded, ensuring no secondary pollution.

\begin{abstract}
Abbreviations
Cd: Cadmium; SSS: Sweet sorghum stalk; 1G: First generation; 2G: Second generation; Chl: Chlorophyll; EdU: Ethynyl deoxyuridine; ROS: Reactive oxygen species; DEGs: Differentially expressed genes; KEGG: Kyoto Encyclopedia of Genes and Genomes; ACdA: Aboveground Cd accumulation; BCF: Bioaccumulation factor; SSB: Sweet sorghum bagasse; SSF: Solid state fermentation; ASSF: Advanced solid-state fermentation; LHW: Liquid hot water; AFEX: Ammonia fiber explosion; QTL: Quantitative trait loci.
\end{abstract}

\section{Acknowledgements}

Not applicable.

\begin{abstract}
Authors' contributions
$\mathrm{XMZ}$ summarized the literatures and wrote the initial draft; SQ and HS optimized the figures and tables, and revised the draft; CWJ and PB revised the draft, mainly focusing on the language and logicality. DZY, YWB, and SZ critically reviewed and commented the manuscript in the prepublication stage. YTQ designed the outline of the draft, supervised and coordinated the execution of this research. All authors read and approved the final manuscript.
\end{abstract}

\section{Funding}

National Key Research and Development Program of China

(2019YFD1 101202); Young Tip-top Talent Project of Science and Technology Innovation by State Forestry and Grassland Administration of China (2019132609); Beijing Forestry University Outstanding Young Talent Cultivation Project (2019JQ03005).

Availability of data and materials

Not applicable.

\section{Declarations}

\section{Consent for publication}

Not applicable.

\section{Competing interests}

The authors declare that they have no known competing financial interests or personal relationships that could have appeared to influence the work reported in this paper.

\section{Author details}

${ }^{1}$ Beijing Key Laboratory of Lignocellulosic Chemistry, Beijing Forestry University, Beijing 100083, China. ${ }^{2}$ Yuan Longping High-Tech Agriculture Co., Ltd, Changsha 410000, China. ${ }^{3}$ Inner Mongolia Lignicell Bio-Refining Co., Ltd, Baotou 014000, China.

Received: 8 August 2021 Accepted: 10 November 2021

Published online: 15 December 2021

\section{References}

1. Vareda JP, Valente AJM, Durães L. Assessment of heavy metal pollution from anthropogenic activities and remediation strategies: a review. J Environ Manag. 2019;246:101-18. https://doi.org/10.1016/j.jenvman. 2019.05.126.

2. Shi T, Zhang Y, Gong Y, Ma J, Wei H, Wu X, et al. Status of cadmium accumulation in agricultural soils across China (1975-2016): from temporal and spatial variations to risk assessment. Chemosphere. 2019;230:13643. https://doi.org/10.1016/j.chemosphere.2019.04.208.

3. He Z, Shentu J, Yang X, Baligar VC, Zhang T, Stoffella PJ. Heavy metal contamination of soils: sources, indicators, and assessment. J Environ Indic. 2015;9:17-8.

4. Ministry of Ecology and Environment of the People's Republic of China. China Ecological Environment Status Bulletin in 2020. 2020. http:// www.mee.gov.cn/hjzl/hjzlqt/trhj/.

5. Burges A, Epelde L, Garbisu C. Impact of repeated single-metal and multi-metal pollution events on soil quality. Chemosphere. 2015;120:815. https://doi.org/10.1016/j.chemosphere.2014.05.037.

6. Lu Y, Song S, Wang R, Liu Z, Meng J, Sweetman AJ, et al. Impacts of soil and water pollution on food safety and health risks in China. Environ Int. 2015;77:5-15. https://doi.org/10.1016/j.envint.2014.12.010.

7. Ali H, Khan E, Sajad MA. Phytoremediation of heavy metals - concepts and applications. Chemosphere. 2013;91:869-81. https://doi.org/10. 1016/j.chemosphere.2013.01.075.

8. DalCorso G, Farinati S, Maistri S, Furini A. How plants cope with cadmium: staking all on metabolism and gene expression. J Integr Plant Biol. 2008;50:1268-80. https://doi.org/10.1111/j.1744-7909.2008. 00737.x.

9. Gong Y, Zhao D, Wang Q. An overview of field-scale studies on remediation of soil contaminated with heavy metals and metalloids: technical progress over the last decade. Water Res. 2018;147:440-60. https://doi. org/10.1016/j.watres.2018.10.024.

10. Liu L, Li W, Song W, Guo M. Remediation techniques for heavy metalcontaminated soils: principles and applicability. Sci Total Environ. 2018;633:206-19. https://doi.org/10.1016/j.scitotenv.2018.03.161.

11. Tang X, Li Q, Wu M, Lin L, Scholz M. Review of remediation practices regarding cadmium-enriched farmland soil with particular reference to China. J Environ Manag. 2016;181:646-62. https://doi.org/10.1016/j. jenvman.2016.08.043.

12. Sathya A, Kanaganahalli V, Rao PS, Gopalakrishnan S. Cultivation of sweet sorghum on heavy metal-contaminated soils by phytoremediation approach for production of bioethanol. In: Prasad MNV, editor. Bioremediation and bioeconomy. Elsevier: New York; 2016. p. 271-92. https://doi.org/10.1016/B978-0-12-802830-8.00012-5.

13. Kumar Yadav K, Gupta N, Kumar A, Reece LM, Singh N, Rezania S, et al. Mechanistic understanding and holistic approach of phytoremediation: a review on application and future prospects. Ecol Eng. 2018;120:27498. https://doi.org/10.1016/j.ecoleng.2018.05.039.

14. Suman J, Uhlik O, Viktorova J, MacekT. Phytoextraction of heavy metals: a promising tool for clean-up of polluted environment? Front Plant Sci. 2018. https://doi.org/10.3389/fpls.2018.01476.

15. Vamerali T, Bandiera M, Mosca G. Field crops for phytoremediation of metal-contaminated land. A review. Environ Chem Lett. 2010;8:1-17. https://doi.org/10.1007/s10311-009-0268-0. 
16. Pogrzeba M, Krzyżak J, Rusinowski S, McCalmont JP, Jensen E. Energy crop at heavy metal-contaminated arable land as an alternative for food and feed production: biomass quantity and quality. In: Sablok $\mathrm{G}$, editor. Plant metallomics and functional omics. Cham: Springer International Publishing; 2019. p. 1-21. https://doi.org/10.1007/ 978-3-030-19103-0_1.

17. Yang Y, Zhou X, Tie B, Peng L, Li H, Wang K, et al. Comparison of three types of oil crop rotation systems for effective use and remediation of heavy metal contaminated agricultural soil. Chemosphere. 2017;188:148-56. https://doi.org/10.1016/j.chemosphere.2017.08.140.

18. Marchiol L, Fellet G, Perosa D, Zerbi G. Removal of trace metals by Sorghum bicolor and Helianthus annuus in a site polluted by industrial wastes: a field experience. Plant Physiol Biochem. 2007;45:379-87. https://doi.org/10.1016/j.plaphy.2007.03.018.

19. Zhuang P, Shu W, Li Z, Liao B, Li J, Shao J. Removal of metals by sorghum plants from contaminated land. J Environ Sci. 2009;21:1432-7. https:// doi.org/10.1016/S1001-0742(08)62436-5

20. Yuan $X$, Xiong T, Yao S, Liu C, Yin Y, Li H, et al. A real filed phytoremediation of multi-metals contaminated soils by selected hybrid sweet sorghum with high biomass and high accumulation ability. Chemosphere. 2019;237:124536. https://doi.org/10.1016/j.chemosphere.2019.124536.

21. Liu Z-Q, Li H-L, Zeng X-J, Lu C, Fu J-Y, Guo L-J, et al. Coupling phytoremediation of cadmium-contaminated soil with safe crop production based on a sorghum farming system. J Clean Prod. 2020;275:123002. https://doi.org/10.1016/j.jclepro.2020.123002.

22. Xiao M-Z, Sun R, Du Z-Y, Yang W-B, Sun Z, Yuan T-Q. A sustainable agricultural strategy integrating $\mathrm{Cd}$-contaminated soils remediation and bioethanol production using sorghum cultivars. Ind Crops Prod 2021;162:113299. https://doi.org/10.1016/j.indcrop.2021.113299.

23. Taha M, Foda M, Shahsavari E, Aburto-Medina A, Adetutu E, Ball A. Commercial feasibility of lignocellulose biodegradation: possibilities and challenges. Curr Opin Biotechnol. 2016;38:190-7. https://doi.org/10. 1016/j.copbio.2016.02.012.

24. Ayodele BV, Alsaffar MA, Mustapa SI. An overview of integration opportunities for sustainable bioethanol production from first- and second-generation sugar-based feedstocks. J Clean Prod. 2020;245: 118857. https://doi.org/10.1016/j.jclepro.2019.118857.

25. Aditiya HB, Mahlia TMI, Chong WT, Nur H, Sebayang AH. Second generation bioethanol production: a critical review. Renew Sustain Energy Rev. 2016;66:631-53. https://doi.org/10.1016/j.rser.2016.07.015.

26. Ahmad Dar R, Ahmad Dar E, Kaur A, Gupta PU. Sweet sorghum-a promising alternative feedstock for biofuel production. Renew Sustain Energy Rev. 2018;82:4070-90. https://doi.org/10.1016/j.rser.2017.10.066

27. Renewable fuel association (RFA). Annual World Fuel Ethanol Production 2021. https://ethanolrfa.org/statistics/annual-ethanol-production/. Accessed July 4, 2021

28. Koçar G, Civaş N. An overview of biofuels from energy crops: current status and future prospects. Renew Sustain Energy Rev. 2013;28:900-16. https://doi.org/10.1016/j.rser.2013.08.022.

29. Sharma B, Larroche C, Dussap C-G. Comprehensive assessment of $2 \mathrm{G}$ bioethanol production. Biores Technol. 2020;313: 123630. https://doi. org/10.1016/j.biortech.2020.123630.

30. El Bassam N. Handbook of bioenergy crops: a complete reference to species, development and applications. 1st ed. London: Routledge; 2010. https://doi.org/10.4324/9781849774789.

31. Mathur S, Umakanth AV, Tonapi VA, Sharma R, Sharma MK. Sweet sorghum as biofuel feedstock: recent advances and available resources. Biotechnol Biofuels. 2017;10:146. https://doi.org/10.1186/ s13068-017-0834-9.

32. Appiah-Nkansah NB, Li J, Rooney W, Wang D. A review of sweet sorghum as a viable renewable bioenergy crop and its techno-economic analysis. Renewable Energy. 2019;143:1121-32. https://doi.org/10. 1016/j.renene.2019.05.066

33. Vinutha KS, Rayaprolu L, Yadagiri K, Umakanth AV, Patil JV, Srinivasa Rao P. Sweet sorghum research and development in India: status and prospects. Sugar Tech. 2014;16:133-43. https://doi.org/10.1007/ s12355-014-0302-9

34. Matsakas L, Christakopoulos P. Optimization of ethanol production from high dry matter liquefied dry sweet sorghum stalks. Biomass Bioenerg. 2013:51:91-8. https://doi.org/10.1016/j.biombioe.2013.01.007.
35. Jafari Y, Amiri H, Karimi K. Acetone pretreatment for improvement of acetone, butanol, and ethanol production from sweet sorghum bagasse. Appl Energy. 2016;168:216-25. https://doi.org/10.1016/j.apene rgy.2016.01.090

36. Dehghanzad M, Shafiei M, Karimi K. Whole sweet sorghum plant as a promising feedstock for biobutanol production via biorefinery approaches: techno-economic analysis. Renewable Energy. 2020;158:332-42. https://doi.org/10.1016/j.renene.2020.05.037.

37. Wang Y, Huo K, Gao L, Zhao G, Wang B, Liu J. Open simultaneous saccharification and fermentation of L-lactic acid by complete utilization of sweet sorghum stalk: a water-saving process. RSC Adv. 2021;11:528490. https://doi.org/10.1039/D0RA09480C.

38. Chen R, Ahmari S, Zhang L. Utilization of sweet sorghum fiber to reinforce fly ash-based geopolymer. J Mater Sci. 2014;49:2548-58. https:// doi.org/10.1007/s10853-013-7950-0.

39. Wang Q, Nnanna PC, Shen F, Huang M, Tian D, Hu J, et al. Full utilization of sweet sorghum for bacterial cellulose production: A concept of material crop. Ind Crops Prod. 2021;162: 113256. https://doi.org/10. 1016/j.indcrop.2021.113256

40. Stamenković OS, Siliveru K, Veljković VB, Banković-Ilić IB, Tasić MB, Ciampitti IA, et al. Production of biofuels from sorghum. Renew Sustain Energy Rev. 2020;124: 109769. https://doi.org/10.1016/j.rser.2020. 109769.

41. Li S, Li G, Zhang L, Zhou Z, Han B, Hou W, et al. A demonstration study of ethanol production from sweet sorghum stems with advanced solid state fermentation technology. Appl Energy. 2013;102:260-5. https:// doi.org/10.1016/j.apenergy.2012.09.060.

42. Whitfield MB, Chinn MS, Veal MW. Processing of materials derived from sweet sorghum for biobased products. Ind Crops Prod. 2012;37:362-75. https://doi.org/10.1016/j.indcrop.2011.12.011.

43. Yuan Y, Yu S, Bañuelos GS, He Y. Accumulation of $\mathrm{Cr}, \mathrm{Cd}, \mathrm{Pb}, \mathrm{Cu}$, and $\mathrm{Zn}$ by plants in tanning sludge storage sites: opportunities for contamination bioindication and phytoremediation. Environ Sci Pollut Res. 2016. https://doi.org/10.1007/s11356-016-7469-4.

44. Bini $C$, Maleci $L$, Romanin A. The chromium issue in soils of the leather tannery district in Italy. J Geochem Explor. 2008;96:194-202. https://doi. org/10.1016/j.gexplo.2007.03.008

45. Velmurugan B, Narra M, Rudakiya DM, Madamwar D. Sweet sorghum: a potential resource for bioenergy production. In: Praveen Kumar R, Raman JK, editors. Refining biomass residues for sustainable energy and bioproducts. Academic Press: New York; 2020. p. 215-42. https:// doi.org/10.1016/B978-0-12-818996-2.00010-7.

46. Venkateswaran K, Sivaraj N, Pandravada SR, Reddy MT, Babu BS. Classification, distribution and biology. In: Aruna C, Visarada KBRS, Venkatesh Bhat B, Tonapi VA, editors. Breeding sorghum for diverse end uses. Woodhead Publishing: Sawston; 2019. p. 33-60. https://doi.org/10. 1016/B978-0-08-101879-8.00003-6.

47. Srinivasa Rao P, Ganesh Kumar C, Reddy BVS. Sweet sorghum: from theory to practice. In: Rao P, Kumar C, editors. Characterization of Improved Sweet Sorghum Cultivars. India: SpringerBriefs in Agriculture. Berlin: Springer; 2013. p. 1-15. https://doi.org/10.1007/978-81-322-0783-2_1.

48. Umakanth AV, Kumar AA, Vermerris W, Tonapi VA. sweet sorghum for biofuel industry. In: Aruna C, Visarada KBRS, Venkatesh Bhat B, Tonapi VA, editors. Breeding sorghum for diverse end uses. Sawston: Woodhead Publishing; 2019. p. 255-70. https://doi.org/10.1016/B978-0-08-1018798.00016-4.

49. Zhao YL, Dolat A, Steinberger Y, Wang X, Osman A, Xie GH. Biomass yield and changes in chemical composition of sweet sorghum cultivars grown for biofuel. Field Crop Res. 2009;111:55-64. https://doi.org/10. 1016/j.fcr.2008.10.006

50. Erickson JE, Helsel ZR, Woodard KR, Vendramini JMB, Wang Y, Sollenberger $L E$, et al. Planting date affects biomass and brix of sweet sorghum grown for biofuel across florida. Agron J. 2011;103:1827-33. https://doi.org/10.2134/agronj2011.0176.

51. Holou RAY, Stevens G. Juice, sugar, and bagasse response of sweet sorghum (Sorghum bicolor (L.) Moench cv. M81E) to N fertilization and soil type. GCB Bioenergy. 2012;4:302-10. https://doi.org/10.1111/j.17571707.2011.01126.x

52. Vasilakoglou I, Dhima K, Karagiannidis N, Gatsis T. Sweet sorghum productivity for biofuels under increased soil salinity and reduced 
irrigation. Field Crop Res. 2011;120:38-46. https://doi.org/10.1016/j.fcr. 2010.08.011.

53. Maw MJW, Houx JH, Fritschi FB. Sweet sorghum ethanol yield component response to nitrogen fertilization. Ind Crops Prod. 2016;84:43-9. https://doi.org/10.1016/j.indcrop.2016.01.038.

54. Ameen A, Yang X, Chen F, Tang C, Du F, Fahad S, et al. Biomass yield and nutrient uptake of energy sorghum in response to nitrogen fertilizer rate on marginal land in a semi-arid region. BioEnergy Research. 2017:10:363-76. https://doi.org/10.1007/s12155-016-9804-5.

55. Geng S, Hills FJ, Johnson SS, Sah RN. Potential yields and on-farm ethanol production cost of corn, sweet sorghum, fodderbeet, and sugarbeet. J Agron Crop Sci. 1989;162:21-9. https://doi.org/10.1111/j. 1439-037X.1989.tb00683.x.

56. Erickson JE, Woodard KR, Sollenberger LE. Optimizing sweet sorghum production for biofuel in the southeastern USA through nitrogen fertilization and top removal. BioEnergy Res. 2012;5:86-94. https://doi. org/10.1007/s12155-011-9129-3.

57. Han LP, Steinberger Y, Zhao YL, Xie GH. Accumulation and partitioning of nitrogen, phosphorus and potassium in different varieties of sweet sorghum. Field Crop Res. 2011;120:230-40. https://doi.org/10.1016/j.fcr. 2010.10.007.

58. Zegada-Lizarazu W, Zatta A, Monti A. Water uptake efficiency and above- and belowground biomass development of sweet sorghum and maize under different water regimes. Plant Soil. 2012;351:47-60. https://doi.org/10.1007/s11104-011-0928-2.

59. Zhan Y, Zhang C, Zheng Q, Huang Z, Yu C. Cadmium stress inhibits the growth of primary roots by interfering auxin homeostasis in Sorghum bicolor seedlings. J Plant Biol. 2017;60:593-603. https://doi.org/10.1007/ s12374-017-0024-0.

60. Kuriakose SV, Prasad MNV. Cadmium stress affects seed germination and seedling growth in Sorghum bicolor (L.) Moench by changing the activities of hydrolyzing enzymes. Plant Growth Regul. 2008;54:143-56. https://doi.org/10.1007/s10725-007-9237-4.

61. Liu D, Hu K, Ma J, Qiu W, Wang X, Zhang S. Effects of cadmium on the growth and physiological characteristics of sorghum plants. Afr J Biotechnol. 2011;10:15770-6. https://doi.org/10.5897/AJB11.848.

62. Soudek P, Petrová Š, Vaňková R, Song J, VaněkT. Accumulation of heavy metals using Sorghum sp. Chemosphere. 2014;104:15-24. https://doi. org/10.1016/j.chemosphere.2013.09.079.

63. Xue ZC, Li JH, Li DS, Li SZ, Jiang CD, Liu LA, et al. Bioaccumulation and photosynthetic activity response of sweet sorghum seedling (Sorghum bicolor L. Moench) to cadmium stress. Photosynthetica. 2018;56:14228. https://doi.org/10.1007/s11099-018-0835-3.

64. Jia W, Lv S, Feng J, Li J, Li Y, Li S. Morphophysiological characteristic analysis demonstrated the potential of sweet sorghum (Sorghum bicolor (L.) Moench) in the phytoremediation of cadmium-contaminated soils. Environ Sci Pollut Res. 2016;23:18823-31. https://doi.org/10. 1007/s11356-016-7083-5.

65. Tian YL, Zhang HY, Guo W, Wei XF. Morphological responses, biomass yield, and bioenergy potential of sweet sorghum cultivated in cadmium-contaminated soil for biofuel. Int J Green Energy. 2015;12:57784. https://doi.org/10.1080/15435075.2013.871722.

66. Liu D, Zhang S, Chen Z, Qiu W. Soil cadmium regulates antioxidases in sorghum. Agricult Sci China. 2010;9:1475-80. https://doi.org/10.1016/ S1671-2927(09)60240-6

67. Feng J, Jia W, Lv S, Bao H, Miao F, Zhang X, et al. Comparative transcriptome combined with morpho-physiological analyses revealed key factors for differential cadmium accumulation in two contrasting sweet sorghum genotypes. Plant Biotechnol J. 2018;16:558-71. https://doi. org/10.1111/pbi.12795.

68. Jia W, Lin K, Lou T, Feng J, Lv S, Jiang P, et al. Comparative analysis of sRNAs, degradome and transcriptomics in sweet sorghum reveals the regulatory roles of miRNAs in Cd accumulation and tolerance. Planta. 2021;254:16. https://doi.org/10.1007/s00425-021-03669-2.

69. Angelova V, Ivanova R, Deliblatovamad VA, Ivanov K. Use of sorghum crops for in situ phytoremediation of polluted soils. J Agric Sci Technol A. 2011;1:693-702.

70. Wang X, Chen C, Wang J. Cadmium phytoextraction from loam soil in tropical southern China by Sorghum bicolor. Int J Phytorem 2017;19:572-8. https://doi.org/10.1080/15226514.2016.1267704.
71. Xue ZC, Li JH, Li SZ, Du RH, Lv P, Ji GS, et al. Study on the phytoremediation potential of energy crop sweet sorghum to Cd-contaminated agriculture soil. Acta Sci Circum. 2018;38:1621-7. https://doi.org/10. 13671/j.hjkxxb.2017.0419.

72. Bai ZQ, Zhu L, Chang HX, Wu JW. Enhancement of cadmium accumulation in sweet sorghum as affected by nitrate. Plant Biol. 2021;23:66-73. https://doi.org/10.1111/plb.13186.

73. Li B, Duan M-M, Zeng X-B, Zhang Q, Xu C, Zhu H-H, et al. Effects of composited organic mobilizing agents and their application periods on cadmium absorption of Sorghum bicolor L. in a Cd-contaminated soil. Chemosphere. 2021;263:128136. https://doi.org/10.1016/j.chemo sphere.2020.128136.

74. Luo S, Xu T, Chen L, Chen J, Rao C, Xiao X, et al. Endophyte-assisted promotion of biomass production and metal-uptake of energy crop sweet sorghum by plant-growth-promoting endophyte Bacillus sp. SLS18. Appl Microbiol Biotechnol. 2012;93:1745-53. https://doi.org/10. 1007/s00253-011-3483-0.

75. Li N, Guo B, Li H, Fu Q, Feng R, Ding Y. Effects of double harvesting on heavy metal uptake by six forage species and the potential for phytoextraction in field. Pedosphere. 2016;26:717-24. https://doi.org/10.1016/ S1002-0160(15)60082-0

76. Jia W, Miao F, Lv S, Feng J, Zhou S, Zhang X, et al. Identification for the capability of Cd-tolerance, accumulation and translocation of 96 sorghum genotypes. Ecotoxicol Environ Saf. 2017;145:391-7. https:// doi.org/10.1016/j.ecoenv.2017.07.002.

77. Tsuboi K, Shehzad T, Yoneda J, Uraguchi S, Ito Y, Shinsei L, et al. Genetic analysis of cadmium accumulation in shoots of sorghum landraces. Crop Sci. 2017;57:22-31. https://doi.org/10.2135/cropsci2016.01.0069.

78. Wang C, Kong Y, Hu R, Zhou G. Miscanthus : A fast-growing crop for environmental remediation and biofuel production. GCB Bioenergy. 2021:13:58-69. https://doi.org/10.1111/gcbb.12761.

79. Danelli T, Sepulcri A, Masetti G, Colombo F, Sangiorgio S, Cassani E, et al. Arundo donax L. Biomass production in a polluted area: effects of two harvest timings on heavy metals uptake. Appl Sci. 2021;11:1147. https:// doi.org/10.3390/app 11031147.

80. Tananonchai A, Sampanpanish P, Chanpiwat P, Tancharakorn S, Sukkha $U$. Effect of EDTA and NTA on cadmium distribution and translocation in Pennisetum purpureum Schum cv Mott. Environ Sci Pollut Res. 2019;26:9851-60. https://doi.org/10.1007/s11356-018-04103-z.

81. Luo J, Qi S, Peng L, Wang J. Phytoremediation efficiency OF CD by Eucalyptus globulus transplanted from polluted and unpolluted sites. Int J Phytorem. 2016;18:308-14. https://doi.org/10.1080/15226514.2015. 1094446.

82. Pulford ID, Riddell-Black D, Stewart C. Heavy metal uptake by willow clones from sewage sludge-treated soil: the potential for phytoremediation. Int J Phytorem. 2002;4:59-72. https://doi.org/10.1080/15226 510208500073.

83. Kubátová P, Hejcman M, Száková J, Vondráčková S, Tlustoš P. Effects of sewage sludge application on biomass production and concentrations of $\mathrm{Cd}, \mathrm{Pb}$ and $\mathrm{Zn}$ in shoots of salix and populus clones: improvement of phytoremediation efficiency in contaminated soils. BioEnergy Research. 2016;9:809-19. https://doi.org/10.1007/s12155-016-9727-1.

84. Dong M, Wang S, Xu F, Wang J, Yang N, Li Q, et al. Pretreatment of sweet sorghum straw and its enzymatic digestion: insight into the structural changes and visualization of hydrolysis process. Biotechnol Biofuels. 2019;12:276. https://doi.org/10.1186/s13068-019-1613-6.

85. Molaverdi M, Karimi K, Khanahmadi M, Goshadrou A. Enhanced sweet sorghum stalk to ethanol by fungus Mucor indicus using solid state fermentation followed by simultaneous saccharification and fermentation. Ind Crops Prod. 2013;49:580-5. https://doi.org/10.1016/j.indcrop.2013. 06.024 .

86. Ostovareh S, Karimi K, Zamani A. Efficient conversion of sweet sorghum stalks to biogas and ethanol using organosolv pretreatment. Ind Crops Prod. 2015;66:170-7. https://doi.org/10.1016/j.indcrop.2014.12.023.

87. Williams DL, Ong RG, Mullet JE, Hodge DB. Integration of pretreatment with simultaneous counter-current extraction of energy sorghum for high-titer mixed sugar production. Front Energy Res. 2019. https://doi. org/10.3389/fenrg.2018.00133.

88. Nozari B, Mirmohamadsadeghi S, Karimi K. Bioenergy production from sweet sorghum stalks via a biorefinery perspective. Appl Microbiol Biotechnol. 2018;102:3425-38. https://doi.org/10.1007/s00253-018-8833-8. 
89. Damay J, Duret X, Ghislain T, Lalonde O, Lavoie J-M. Steam explosion of sweet sorghum stems: optimisation of the production of sugars by response surface methodology combined with the severity factor. Ind Crops Prod. 2018;111:482-93. https://doi.org/10.1016/j.indcrop.2017.11. 006.

90. Damay J, Boboescu I-Z, Duret X, Lalonde O, Lavoie J-M. A novel hybrid first and second generation hemicellulosic bioethanol production process through steam treatment of dried sorghum biomass. Biores Technol. 2018;263:103-11. https://doi.org/10.1016/j.biortech.2018.04. 045.

91. Li M, Feng S, Wu L, Li Y, Fan C, Zhang R, et al. Sugar-rich sweet sorghum is distinctively affected by wall polymer features for biomass digestibility and ethanol fermentation in bagasse. Biores Technol. 2014;167:1423. https://doi.org/10.1016/j.biortech.2014.04.086.

92. Diallo B, Li M, Tang C, Ameen A, Zhang W, Xie GH. Biomass yield, chemical composition and theoretical ethanol yield for different genotypes of energy sorghum cultivated on marginal land in China. Ind Crops Prod. 2019;137:221-30. https://doi.org/10.1016/j.indcrop.2019.05.030.

93. Sipos B, Réczey J, Somorai Z, Kádár Z, Dienes D, Réczey K. Sweet sorghum as feedstock for ethanol production: enzymatic hydrolysis of steam-pretreated bagasse. Appl Biochem Biotechnol. 2009;153:151-62. https://doi.org/10.1007/s12010-008-8423-9.

94. Cole MR, Eggleston G, Petrie E, Uchimiya SM, Dalley C. Cultivar and maturity effects on the quality attributes and ethanol potential of sweet sorghum. Biomass Bioenerg. 2017;96:183-92. https://doi.org/10. 1016/j.biombioe.2016.12.001.

95. Qazi HA, Paranjpe S, Bhargava S. Stem sugar accumulation in sweet sorghum - activity and expression of sucrose metabolizing enzymes and sucrose transporters. J Plant Physiol. 2012;169:605-13. https://doi. org/10.1016/j.jplph.2012.01.005.

96. Davila-Gomez FJ, Chuck-Hernandez C, Perez-Carrillo E, Rooney WL, Serna-Saldivar SO. Evaluation of bioethanol production from five different varieties of sweet and forage sorghums (Sorghum bicolor $(\mathrm{L}$ ) Moench). Ind Crops Prod. 2011;33:611-6. https://doi.org/10.1016/j.inder op.2010.12.022.

97. López-Sandin I, Gutiérrez-Soto G, Gutiérrez-Díez A, Medina-Herrera N, Gutiérrez-Castorena E, Galicia-Juárez M, et al. Biomass and sugar production dynamics in sweet sorghum variety Roger. Chilean J Agric Res. 2021;81:92-101. https://doi.org/10.4067/S0718-583920210001000 92.

98. Guigou M, Lareo C, Pérez LV, Lluberas ME, Vázquez D, Ferrari MD. Bioethanol production from sweet sorghum: Evaluation of post-harvest treatments on sugar extraction and fermentation. Biomass Bioenerg. 2011;35:3058-62. https://doi.org/10.1016/j.biombioe.2011.04.028.

99. Wu X, Staggenborg S, Propheter JL, Rooney WL, Yu J, Wang D. Features of sweet sorghum juice and their performance in ethanol fermentation. Ind Crops Prod. 2010;31:164-70. https://doi.org/10.1016/j.indcrop.2009. 10.006.

100. Eggleston G, Cole M, Andrzejewski B. New Commercially viable processing technologies for the production of sugar feedstocks from sweet sorghum (Sorghum bicolor L. Moench) for manufacture of biofuels and bioproducts. Sugar Tech. 2013;15:232-49. https://doi.org/ 10.1007/s12355-013-0229-6.

101. Eggleston G, DeLucca A, Sklanka S, Dalley C, St. Cyr E, Powell R. Investigation of the stabilization and preservation of sweet sorghum juices. Ind Crops Prod. 2015;64:258-70. https://doi.org/10.1016/j.indcrop.2014. 09.008.

102. Laopaiboon L, Thanonkeo P, Jaisil P, Laopaiboon P. Ethanol production from sweet sorghum juice in batch and fed-batch fermentations by Saccharomyces cerevisiae. World J Microbiol Biotechnol. 2007;23:1497501. https://doi.org/10.1007/s11274-007-9383-x.

103. Kim M, Day DF. Composition of sugar cane, energy cane, and sweet sorghum suitable for ethanol production at Louisiana sugar mills. J Ind Microbiol Biotechnol. 2011;38:803-7. https://doi.org/10.1007/ s10295-010-0812-8.

104. Barcelos CA, Maeda RN, Santa Anna LMM, Pereira N. Sweet sorghum as a whole-crop feedstock for ethanol production. Biomass Bioenerg. 2016;94:46-56. https://doi.org/10.1016/j.biombioe.2016.08.012.

105. Castro E, Nieves IU, Rondón V, Sagues WJ, Fernández-Sandoval MT, Yomano LP, et al. Potential for ethanol production from different sorghum cultivars. Ind Crops Prod. 2017;109:367-73. https://doi.org/10. 1016/j.indcrop.2017.08.050.

106. Zhang C, Wen H, Chen C, Cai D, Fu C, Li P, et al. Simultaneous saccharification and juice co-fermentation for high-titer ethanol production using sweet sorghum stalk. Renewable Energy. 2019;134:44-53. https:// doi.org/10.1016/j.renene.2018.11.005.

107. Sriputorn B, Laopaiboon P, Phukoetphim N, Polsokchuak N, Butkun K, Laopaiboon L. Enhancement of ethanol production efficiency in repeated-batch fermentation from sweet sorghum stem juice: effect of initial sugar, nitrogen and aeration. Electron J Biotechnol. 2020;46:5564. https://doi.org/10.1016/j.ejbt.2020.06.001.

108. Sasaki K, Tsuge Y, Sasaki D, Kawaguchi H, Sazuka T, Ogino C, et al. Repeated ethanol production from sweet sorghum juice concentrated by membrane separation. Biores Technol. 2015;186:351-5. https://doi. org/10.1016/j.biortech.2015.03.127.

109. Sasaki K, Tsuge Y, Kawaguchi H, Yasukawa M, Sasaki D, Sazuka T, et al. Sucrose purification and repeated ethanol production from sugars remaining in sweet sorghum juice subjected to a membrane separation process. Appl Microbiol Biotechnol. 2017;101:6007-14. https://doi. org/10.1007/s00253-017-8316-3.

110. Wijaya H, Sasaki K, Kahar P, Yopi, Kawaguchi H, Sazuka T, et al. Repeated ethanol fermentation from membrane-concentrated sweet sorghum juice using the flocculating yeast Saccharomyces cerevisiae F118 strain. Bioresour Technol. 2018;265:542-7. https://doi.org/10.1016/j.biortech. 2018.07.039.

111. Liu R, Shen F. Impacts of main factors on bioethanol fermentation from stalk juice of sweet sorghum by immobilized Saccharomyces cerevisiae (CICC 1308). Biores Technol. 2008;99:847-54. https://doi.org/10.1016/j. biortech.2007.01.009.

112. Liu R, Li J, Shen F. Refining bioethanol from stalk juice of sweet sorghum by immobilized yeast fermentation. Renewable Energy. 2008:33:1130-5. https://doi.org/10.1016/j.renene.2007.05.046.

113. Laopaiboon L, Laopaiboon P. Ethanol production from sweet sorghum juice in repeated-batch fermentation by Saccharomyces cerevisiae immobilized on corncob. World J Microbiol Biotechnol. 2012;28:559-66. https://doi.org/10.1007/s11274-011-0848-6.

114. Ariyajaroenwong P, Laopaiboon P, Jaisil P, Laopaiboon L. Repeatedbatch ethanol production from Sweet Sorghum Juice by Saccharomyces cerevisiae immobilized on Sweet Sorghum Stalks. Energies. 2012;5:1215-28. https://doi.org/10.3390/en5041215.

115. Laopaiboon L, Nuanpeng S, Srinophakun P, Klanrit P, Laopaiboon P. Ethanol production from sweet sorghum juice using very high gravity technology: effects of carbon and nitrogen supplementations. Biores Technol. 2009;100:4176-82. https://doi.org/10.1016/j.biortech.2009.03. 046.

116. Deesuth $\mathrm{O}$, Laopaiboon P, Klanrit P, Laopaiboon L. Improvement of ethanol production from sweet sorghum juice under high gravity and very high gravity conditions: Effects of nutrient supplementation and aeration. Ind Crops Prod. 2015;74:95-102. https://doi.org/10.1016/j. indcrop.2015.04.068.

117. Appiah-Nkansah NB, Zhang K, Rooney W, Wang D. Ethanol production from mixtures of sweet sorghum juice and sorghum starch using very high gravity fermentation with urea supplementation. Ind Crops Prod. 2018;111:247-53. https://doi.org/10.1016/j.indcrop.2017.10.028.

118. Rein P. Cane sugar engineering. Berlin: Verlag Dr. Albert Bartens KG; 2007.

119. Appiah-Nkansah NB, Zhang K, Rooney W, Wang D. Model study on extraction of fermentable sugars and nonstructural carbohydrate from sweet sorghum using diffusion process. Ind Crops Prod. 2016;83:65462. https://doi.org/10.1016/j.indcrop.2015.12.056.

120. Jia F, Chawhuaymak J, Riley MR, Zimmt W, Ogden KL. Efficient extraction method to collect sugar from sweet sorghum. J Biol Eng. 2013;7:1. https://doi.org/10.1186/1754-1611-7-1.

121. Koo B, Park J, Gonzalez R, Jameel H, Park S. Two-stage autohydrolysis and mechanical treatment to maximize sugar recovery from sweet sorghum bagasse. Biores Technol. 2019;276:140-5. https://doi.org/10. 1016/j.biortech.2018.12.112.

122. Baah Appiah-Nkansah N, Li J, Zhang K, Zhang M, Wang D. Study on mass transfer kinetics of sugar extraction from Sweet Sorghum biomass via diffusion process and ethanol yield using SSF. Processes. 2019;7:137. https://doi.org/10.3390/pr7030137. 
123. Thomas L, Larroche C, Pandey A. Current developments in solid-state fermentation. Biochem Eng J. 2013;81:146-61. https://doi.org/10.1016/j. bej.2013.10.013.

124. Du R, Yan J, Feng Q, Li P, Zhang L, Chang S, et al. A Novel Wild-Type Saccharomyces cerevisiae Strain TSH1 in scaling-up of solid-state fermentation of ethanol from sweet sorghum stalks. PLoS ONE. 2014;9: e94480. https://doi.org/10.1371/journal.pone.0094480.

125. Yu J, XuZhang, Tan T. Ethanol production by solid state fermentation of sweet sorghum using thermotolerant yeast strain. Fuel Process Technol. 2008;89:1056-9. https://doi.org/10.1016/j.fuproc.2008.04.008.

126. Shen F, Liu R. Research on solid-state ethanol fermentation using dry sweet sorghum stalk particles with active dry yeast. Energy Fuels. 2009;23:519-25. https://doi.org/10.1021/ef800531e.

127. Kwon Y-J, Wang F, Liu C-Z. Deep-bed solid state fermentation of sweet sorghum stalk to ethanol by thermotolerant Issatchenkia orientalis IPE 100. Biores Technol. 2011;102:11262-5. https://doi.org/10.1016/j.biort ech.2011.09.103.

128. Fu X, Li P, Zhang L, Li S. RNA-Seq-based transcriptomic analysis of Saccharomyces cerevisiae during solid-state fermentation of crushed sweet sorghum stalks. Process Biochem. 2018;68:53-63. https://doi.org/ 10.1016/j.procbio.2018.02.024

129. Li G, Li J, Li S, Zu X, Zhang L, Qi L, et al. Extraction of bioethanol from fermented sweet sorghum bagasse by batch distillation. Korean J Chem Eng. 2017:34:127-32. https://doi.org/10.1007/s11814-016-0226-z.

130. Han B, Wang L, Li SZ, Wang EQ, Zhang L, Li TC. Ethanol production from sweet sorghum stalks by advanced solid state fermentation (ASSF) technology. Sheng Wu Gong Cheng Xue Bao/Chin J Biotechnol. 2010;26:966-73.

131. Li J, Li S, Han B, Yu M, Li G, Jiang Y. A novel cost-effective technology to convert sucrose and homocelluloses in sweet sorghum stalks into ethanol. Biotechnol Biofuels. 2013;6:174. https://doi.org/10.1186/ 1754-6834-6-174

132. Yu M, Li J, Li S, Du R, Jiang Y, Fan G, et al. A cost-effective integrated process to convert solid-state fermented sweet sorghum bagasse into cellulosic ethanol. Appl Energy. 2014;115:331-6. https://doi.org/10. 1016/j.apenergy.2013.11.020.

133. Yu M, Li J, Chang S, Zhang L, Mao Y, Cui T, et al. Bioethanol production using the sodium hydroxide pretreated sweet sorghum bagasse without washing. Fuel. 2016;175:20-5. https://doi.org/10.1016/j.fuel.2016.02. 012.

134. Pham HTT, Nghiem NP, Kim TH. Near theoretical saccharification of sweet sorghum bagasse using simulated green liquor pretreatment and enzymatic hydrolysis. Energy. 2018;157:894-903. https://doi.org/10. 1016/j.energy.2018.06.005.

135. Marx S, Ndaba B, Chiyanzu I, Schabort C. Fuel ethanol production from sweet sorghum bagasse using microwave irradiation. Biomass Bioenerg. 2014;65:145-50. https://doi.org/10.1016/j.biombioe.2013.11.019.

136. Himmel ME, Ding S-Y, Johnson DK, Adney WS, Nimlos MR, Brady JW, et al. Biomass recalcitrance: engineering plants and enzymes for biofuels production. Science. 2007;315:804-7. https://doi.org/10.1126/scien ce.1137016.

137. Kumar P, Barrett DM, Delwiche MJ, Stroeve P. Methods for pretreatment of Lignocellulosic biomass for efficient hydrolysis and biofuel production. Ind Eng Chem Res. 2009;48:3713-29. https://doi.org/10.1021/ ie801542g.

138. Agbor VB, Cicek N, Sparling R, Berlin A, Levin DB. Biomass pretreatment: fundamentals toward application. Biotechnol Adv. 2011;29:675-85. https://doi.org/10.1016/j.biotechadv.2011.05.005.

139. Li D, Long L, Ding S. Alkaline organosolv pretreatment of different sorghum stem parts for enhancing the total reducing sugar yields and p-coumaric acid release. Biotechnol Biofuels. 2020;13:106. https://doi. org/10.1186/s13068-020-01746-4.

140. Cai D, Chang Z, Wang C, Ren W, Wang Z, Qin P, et al. Impact of sweet sorghum cuticular waxes (SSCW) on acetone-butanol-ethanol fermentation using Clostridium acetobutylicum ABE1201. Biores Technol. 2013:149:470-3. https://doi.org/10.1016/j.biortech.2013.09.122.

141. Zhang J, Ma X, Yu J, Zhang X, Tan T. The effects of four different pretreatments on enzymatic hydrolysis of sweet sorghum bagasse. Biores Technol. 2011;102:4585-9. https://doi.org/10.1016/j.biortech.2010.12. 093.
142. Wu L, Arakane M, Ike M, Wada M, Takai T, Gau M, et al. Low temperature alkali pretreatment for improving enzymatic digestibility of sweet sorghum bagasse for ethanol production. Biores Technol. 2011;102:47939. https://doi.org/10.1016/j.biortech.2011.01.023.

143. Goshadrou A, Karimi K, Taherzadeh MJ. Bioethanol production from sweet sorghum bagasse by Mucor hiemalis. Ind Crops Prod. 2011:34:1219-25. https://doi.org/10.1016/j.indcrop.2011.04.018.

144. Cao W, Sun C, Liu R, Yin R, Wu X. Comparison of the effects of five pretreatment methods on enhancing the enzymatic digestibility and ethanol production from sweet sorghum bagasse. Biores Technol. 2012;111:215-21. https://doi.org/10.1016/j.biortech.2012.02.034.

145. Umagiliyage AL, Choudhary R, Liang Y, Haddock J, Watson DG. Laboratory scale optimization of alkali pretreatment for improving enzymatic hydrolysis of sweet sorghum bagasse. Ind Crops Prod. 2015;74:977-86. https://doi.org/10.1016/j.indcrop.2015.05.044.

146. Yan Z, Li J, Chang S, Cui T, Jiang Y, Yu M, et al. Lignin relocation contributed to the alkaline pretreatment efficiency of sweet sorghum bagasse. Fuel. 2015;158:152-8. https://doi.org/10.1016/j.fuel.2015.05.029.

147. Thanapimmetha A, Saisriyoot M, Khomlaem C, Chisti Y, Srinophakun P. A comparison of methods of ethanol production from sweet sorghum bagasse. Biochem Eng J. 2019;151: 107352. https://doi.org/10.1016/j. bej.2019.107352.

148. Heredia-Olea E, Pérez-Carrillo E, Serna-Saldívar SO. Production of ethanol from sweet sorghum bagasse pretreated with different chemical and physical processes and saccharified with fiber degrading enzymes. Biores Technol. 2013;134:386-90. https://doi.org/10.1016/j.biortech. 2013.01.162.

149. Wang L, Luo Z, Shahbazi A. Optimization of simultaneous saccharification and fermentation for the production of ethanol from sweet sorghum (Sorghum bicolor) bagasse using response surface methodology. Ind Crops Prod. 2013;42:280-91. https://doi.org/10.1016/j.indcrop. 2012.06.005.

150. Darkwah K, Wang L, Shahbazi A. Simultaneous saccharification and fermentation of sweet sorghum after acid pretreatment. Energy Sources Part A Recovery Util Environ Effects. 2016;38:1485-92. https://doi.org/ 10.1080/15567036.2012.724146

151. Banerji A, Kishore WVN, Balakrishnan M. A comparison of pretreatments on release of sugars from sweet sorghum bagasse for bioethanol production. Int J Green Energy. 2017;14:522-7. https://doi.org/10.1080/ 15435075.2014 .888658$.

152. Partida-Sedas G, Montes-García N, Carvajal-Zarrabal O, López-Zamora L, Gómez-Rodríguez J, Aguilar-Uscanga MG. Optimization of hydrolysis process to obtain fermentable sugars from Sweet Sorghum Bagasse using a Box-Behnken design. Sugar Tech. 2017;19:317-25. https://doi. org/10.1007/s12355-016-0461-y.

153. Joy SP, Kumar AA, Gorthy S, Jaganathan J, Kunappareddy A, Gaddameedi A, et al. Variations in structure and saccharification efficiency of biomass of different sorghum varieties subjected to aqueous ammonia and glycerol pretreatments. Ind Crops Prod. 2021;159: 113072. https:// doi.org/10.1016/j.indcrop.2020.113072.

154. Chen C, Boldor D, Aita G, Walker M. Ethanol production from sorghum by a microwave-assisted dilute ammonia pretreatment. Biores Technol. 2012;110:190-7. https://doi.org/10.1016/j.biortech.2012.01.021.

155. Xu Q-Q, Zhao M-J, Yu Z-Z, Yin J-Z, Li G-M, Zhen M-Y, et al. Enhancing enzymatic hydrolysis of corn cob, corn stover and sorghum stalk by dilute aqueous ammonia combined with ultrasonic pretreatment. Ind Crops Prod. 2017;109:220-6. https://doi.org/10.1016/j.indcrop.2017.08. 038.

156. Xu F, Wang J, Dong M, Wang S, Xiao G, Li Q, et al. Enhancing enzymatic hydrolysis yield of sweet sorghum straw polysaccharides by heavy ion beams irradiation pretreatment. Carbohyd Polym. 2019;222: 114976. https://doi.org/10.1016/j.carbpol.2019.114976.

157. Wahyono T, Lelananingtyas N, Sihono S. Effects of Gamma Irradiation on Ruminal Degradation of Samurai 1 Sweet Sorghum Bagasse. Atom Indonesia. 2017;43:35. https://doi.org/10.17146/aij.2017.620.

158. Heredia-Olea E, Pérez-Carrillo E, Serna-Saldívar SO. Effects of different acid hydrolyses on the conversion of sweet sorghum bagasse into $C 5$ and C6 sugars and yeast inhibitors using response surface methodology. Biores Technol. 2012;119:216-23. https://doi.org/10.1016/j.biort ech.2012.05.122. 
159. Jiang T-T, Zhou X, Liang Y, Jiang A-L, Liang J-P. Effects of different stem skin and marrow root mesh sizes in Sweet Sorghum Bagasse on the release of sugar in hydrolysis. Sugar Tech. 2019;21:421-36. https://doi. org/10.1007/s12355-018-0664-5.

160. Teramura H, Sasaki K, Oshima T, Kawaguchi H, Ogino C, Sazuka T, et al. Effective usage of sorghum bagasse: optimization of organosolv pretreatment using 25\% 1-butanol and subsequent nanofiltration membrane separation. Biores Technol. 2018;252:157-64. https://doi. org/10.1016/j.biortech.2017.12.100.

161. Yu Q, Zhuang X, Yuan Z, Wang W, Qi W, Wang Q, et al. Step-change flow rate liquid hot water pretreatment of sweet sorghum bagasse for enhancement of total sugars recovery. Appl Energy. 2011;88:2472-9. https://doi.org/10.1016/j.apenergy.2011.01.031.

162. Yu Q, Zhuang X, Wang W, Qi W, Wang Q, Tan X, et al. Hemicellulose and lignin removal to improve the enzymatic digestibility and ethanol production. Biomass Bioenergy. 2016;94:105-9. https://doi.org/10.1016/j. biombioe.2016.08.005.

163. Shen F, Saddler JN, Liu R, Lin L, Deng S, Zhang Y, et al. Evaluation of steam pretreatment on sweet sorghum bagasse for enzymatic hydrolysis and bioethanol production. Carbohyd Polym. 2011;86:1542-8. https://doi.org/10.1016/j.carbpol.2011.06.059.

164. Li B-Z, Balan V, Yuan Y-J, Dale BE. Process optimization to convert forage and sweet sorghum bagasse to ethanol based on ammonia fiber expansion (AFEX) pretreatment. Biores Technol. 2010;101:1285-92. https://doi.org/10.1016/j.biortech.2009.09.044.

165. Mishra V, Jana AK, Jana MM, Gupta A. Fungal pretreatment of sweet sorghum bagasse with supplements: improvement in lignin degradation, selectivity and enzymatic saccharification. 3 Biotech. 2017;7:110. https://doi.org/10.1007/s13205-017-0719-4.

166. Matsakas L, Christakopoulos P. Fermentation of liquefacted hydrothermally pretreated sweet sorghum bagasse to ethanol at high-solids content. Biores Technol. 2013;127:202-8. https://doi.org/10.1016/j.biort ech.2012.09.107.

167. Sun S-L, Sun S-N, Wen J-L, Zhang X-M, Peng F, Sun R-C. Assessment of integrated process based on hydrothermal and alkaline treatments for enzymatic saccharification of sweet sorghum stems. Biores Technol. 2015;175:473-9. https://doi.org/10.1016/j.biortech.2014.10.111.

168. Li P, Cai D, Zhang C, Li S, Qin P, Chen C, et al. Comparison of two-stage acid-alkali and alkali-acid pretreatments on enzymatic saccharification ability of the sweet sorghum fiber and their physicochemical characterizations. Biores Technol. 2016;221:636-44. https://doi.org/10.1016/j. biortech.2016.09.075

169. Li X, Xu R, Yang J, Nie S, Liu D, Liu Y, et al. Production of 5-hydroxymethylfurfural and levulinic acid from lignocellulosic biomass and catalytic upgradation. Ind Crops Prod. 2019;130:184-97. https://doi.org/10. 1016/j.indcrop.2018.12.082.

170. Damay J, Boboescu I-Z, Beigbeder J-B, Duret X, Beauchemin S, Lalonde $\mathrm{O}$, et al. Single-stage extraction of whole sorghum extractives and hemicelluloses followed by their conversion to ethanol. Ind Crops Prod. 2019;137:636-45. https://doi.org/10.1016/j.indcrop.2019.05.028.

171. Upadhyaya HD, Sharma S, Dwivedi SL, Singh SK. Genetics, genomics and breeding of sorghum. 1st ed. Cambridge: CRC Press; 2014. https:// doi.org/10.1201/b17153.

172. Rakshit S, Bellundagi A. Conventional breeding techniques in sorghum. In: Aruna C, Visarada KBRS, Venkatesh Bhat B, Tonapi VA, editors. Breeding sorghum for diverse end uses. Sawston: Woodhead Publishing; 2019. p. 77-91. https://doi.org/10.1016/B978-0-08-101879-8.00005-X.

173. Madhusudhana R. Marker-assisted breeding in sorghum. In: Aruna C, Visarada KBRS, Venkatesh Bhat B, Tonapi VA, editors. Breeding sorghum for diverse end uses. Sawston: Woodhead Publishing; 2019. p. 93-114. https://doi.org/10.1016/B978-0-08-101879-8.00006-1.

174. Balakrishna D, Vinodh R, Madhu P, Avinash S, Rajappa PV, Bhat BV. Tissue Culture and Genetic Transformation in Sorghum bicolor. In: Aruna C, Visarada KBRS, Venkatesh Bhat B, Tonapi VA, editors. Breeding sorghum for diverse end uses. Sawston: Woodhead Publishing; 2019. p. 115-30. https://doi.org/10.1016/B978-0-08-101879-8.00007-3.

175. Anami SE, Zhang L, Xia Y, Zhang Y, Liu Z, Jing H. Sweet sorghum ideotypes: genetic improvement of the biofuel syndrome. Food Energy Security. 2015;4:159-77. https://doi.org/10.1002/fes3.63.
176. Calviño M, Messing J. Sweet sorghum as a model system for bioenergy crops. Curr Opin Biotechnol. 2012;23:323-9. https://doi.org/10.1016/j. copbio.2011.12.002

177. Gao Y, Lipton AS, Wittmer Y, Murray DT, Mortimer JC. A grass-specific cellulose-xylan interaction dominates in sorghum secondary cell walls. Nat Commun. 2020;11:6081. https://doi.org/10.1038/ s41467-020-19837-z.

\section{Publisher's Note}

Springer Nature remains neutral with regard to jurisdictional claims in published maps and institutional affiliations.

\section{Submit your manuscript to a SpringerOpen ${ }^{\odot}$ journal and benefit from:}

- Convenient online submission

- Rigorous peer review

- Open access: articles freely available online

- High visibility within the field

Retaining the copyright to your article

Submit your next manuscript at springeropen.com 